\title{
Environmental radioactivity in the UK: the airborne geophysical view of dose rate estimates
}

David Beamish

Journal of Environmental Radioactivity, Volume 138, December 2014, Pages 249-263

http://dx.doi.org/10.1016/i.jenvrad.2014.08.025

\section{Corresponding author:}

David Beamish, British Geological Survey, Keyworth, Nottingham, NG12 5GG, UK

Email: dbe@bgs.ac.uk

Tel: +44(0)1159363432

Fax: +44(0)115936 3437

\section{Keywords:}

Gamma-ray; Soil; Bedrock; Airborne; UK

\section{Highlights:}

- UK airborne estimates of dose rates have been obtained across $40,000 \mathrm{~km}^{2}$.

- Spatial mapping densities range from 10 to $50 \mathrm{~m}$.

- Wide scale (geological) and localized (technological) effects are quantified

- Theory and data indicate soil attenuation effects are pervasive

- Comparison of ground geochemical and airborne dose estimates 
This study considers UK airborne gamma-ray data obtained through a series of high spatial resolution, low altitude surveys over the past decade. The ground concentrations of the naturally occurring radionuclides Potassium, Thorium and Uranium are converted to air absorbed dose rates and these are used to assess terrestrial exposure levels from both natural and technologically enhanced sources. The high resolution airborne information is also assessed alongside existing knowledge from soil sampling and ground-based measurements of exposure levels. The surveys have sampled an extensive number of the UK lithological bedrock formations and the statistical information provides examples of low dose rate lithologies (the formations that characterise much of southern England) to the highest sustained values associated with granitic terrains. The maximum dose rates (e.g. $>300 \mathrm{nGy} \cdot \mathrm{h}^{-1}$ ) encountered across the sampled granitic terrains are found to vary by a factor of 2. Excluding granitic terrains, the most spatially extensive dose rates (>50 nGy. $\mathrm{h}^{-1}$ ) are found in association with the Mercia Mudstone Group (Triassic argillaceous mudstones) of eastern England. Geological associations between high dose rate and high radon values are also noted. Recent studies of the datasets has revealed the extent of source rock (i.e. bedrock) flux attenuation by soil moisture in conjunction with the density and porosity of the temperate latitude soils found in the UK. The presence or absence of soil cover (and associated presence or absence of attenuation) appears to account for a range of localised variations in the exposure levels encountered. The hypothesis is supported by a study of an extensive combined data set of dose rates obtained from soil sampling and by airborne geophysical survey. With no attenuation factors applied, except those intrinsic to the airborne estimates, a bias to high values of between 10 and $15 \mathrm{nGy} \cdot \mathrm{h}^{-1}$ is observed in the soil data. A wide range of technologically enhanced, localised contributions to dose rate values are also apparent in the data sets. Two detailed examples are provided that reveal the detectability of site-scale environmental impacts due to former industrial activities and the high dose values $\left(>500 \mathrm{nGy} \cdot \mathrm{h}^{-1}\right)$ that are associated with former, small-scale Uranium mining operations. 


\section{Introduction}

Terrestrial gamma radiation accounts for $>80 \%$ of the total dose of ionising radiation to which the population is exposed. The average annual dose to the UK population is estimated to be $2.7 \mathrm{mSV}$ with $2.2 \mathrm{mSv}$ (or $81 \%$ of the total) of this coming from natural radiation (Hughes et al., 2005). Two national gamma-ray dose surveys conducted in 1989 found arithmetic means of $34 \mathrm{nGy} \cdot \mathrm{h}^{-1}$ and 23 nGy. $h^{-1}$ for Great Britain (Green et al., 1989) and Northern Ireland (Caulfield and Ledgerwood, 1989), respectively. The first national-scale gamma spectrometry survey was reported by Tyler and Copplestone (2007) using 128 field spectrometric measurements sampled across the UK. The air absorbed dose rates (Air Kerma) for the UK were reported to be in the range from 8 to $60 \mathrm{nGy} \cdot \mathrm{h}^{-1}$.

Airborne radiometric (gamma-ray spectrometric, referred to here as airborne spectrometry (AS) measurements routinely acquire information on the ground concentrations of the three most significant, natural primordial radionuclides in the environment. Uranium $\left({ }^{238} \mathrm{U}\right)$ and Thorium $\left({ }^{232} \mathrm{Th}\right)$ undergo radioactive decay through a series of decay products eventually producing stable isotopes of lead. These two radionuclides, together with Potassium $\left({ }^{40} \mathrm{~K}\right)$, are present in bedrock, superficial geology and soils. Gamma dose rates largely reflect the natural variation of Potassium, Uranium and Thorium across the environment. Their natural variability across significant areas of the UK has been assessed in a series of airborne radiometric surveys conducted over the past decade. The high spatial resolution of the surveys, and their continuous local to regional scale, allow assessments of both the geological background and its spatial variability together with localised concentrations due to industrial/technological processes. The data sets obtained thus provide a basis for both NORM (naturally occurring radioactive materials) and TENORM (technologically enhanced naturally occurring radioactive materials) studies of dose rates. Of significance is the fact that the airborne studies provide continuous local to regional scale assessments. The airborne assessments of dose rates may be considered in relation to existing, and more conventional, soil sampling and above ground assessments. Conventional dosimetry assessments are undertaken using soil sampling and subsequent laboratory (e.g. X-ray fluorescence, XRF) analysis (e.g. Johnson et al., 2005). These techniques are referred to here as soil spectrometry (SS). Alternative ground-based spectrometer surveys (sometimes called in-situ surveys) may be undertaken (Macdonald et al., 1996; Tyler et al., 1996). Such techniques are referred to here as ground spectrometry (GS). These measurements, together with airborne observations, provide direct measures of dose rates in air (air absorbed dose, $A A D)$. The ground spectrometric observations, obtained at an elevation of about $1 \mathrm{~m}$, are typically most sensitive to a ground area of typical radius of $8 \mathrm{~m}$ (e.g. Tyler et al., 1996); in the airborne case, with typical elevations of $>60 \mathrm{~m}$, the footprint radius will exceed $100 \mathrm{~m}$.

The airborne measurements may be used to provide assessments to the dose rate contributions made by the individual radioelements. About one half of the annual UK terrestrial dose rate of 2.2 $\mathrm{mSv}$ is estimated to come from indoor radon (Watson et al., 2005). Radium $\left({ }^{226} \mathrm{Ra}\right.$ ) is the fifth daughter product of Uranium $\left({ }^{238} \mathrm{U}\right)$ and radium is also the parent of the natural gas radon ${ }^{222} \mathrm{Rn}$ responsible for radon exposure of the population. The airborne measurements of Uranium therefore provide one of the supporting techniques in the estimation of indoor radon levels alongside known 
and predicted geological controls (Emery et al., 2005a; Appleton et al., 2008). Radon potential information in the UK (Scheib et al., 2013) is produced by assessing measurements of radon concentration in homes grouped by underlying geology. Detailed studies of the relationships between radon potential, ground-based spectrometry (GS) and airborne measurements (AS) are provided by Emery et al. (2005a). Ground-based gamma spectrometry measurements of Uranium, Potassium and Thorium were found to be correlated with the airborne measurements at the $99.95 \%$ level.

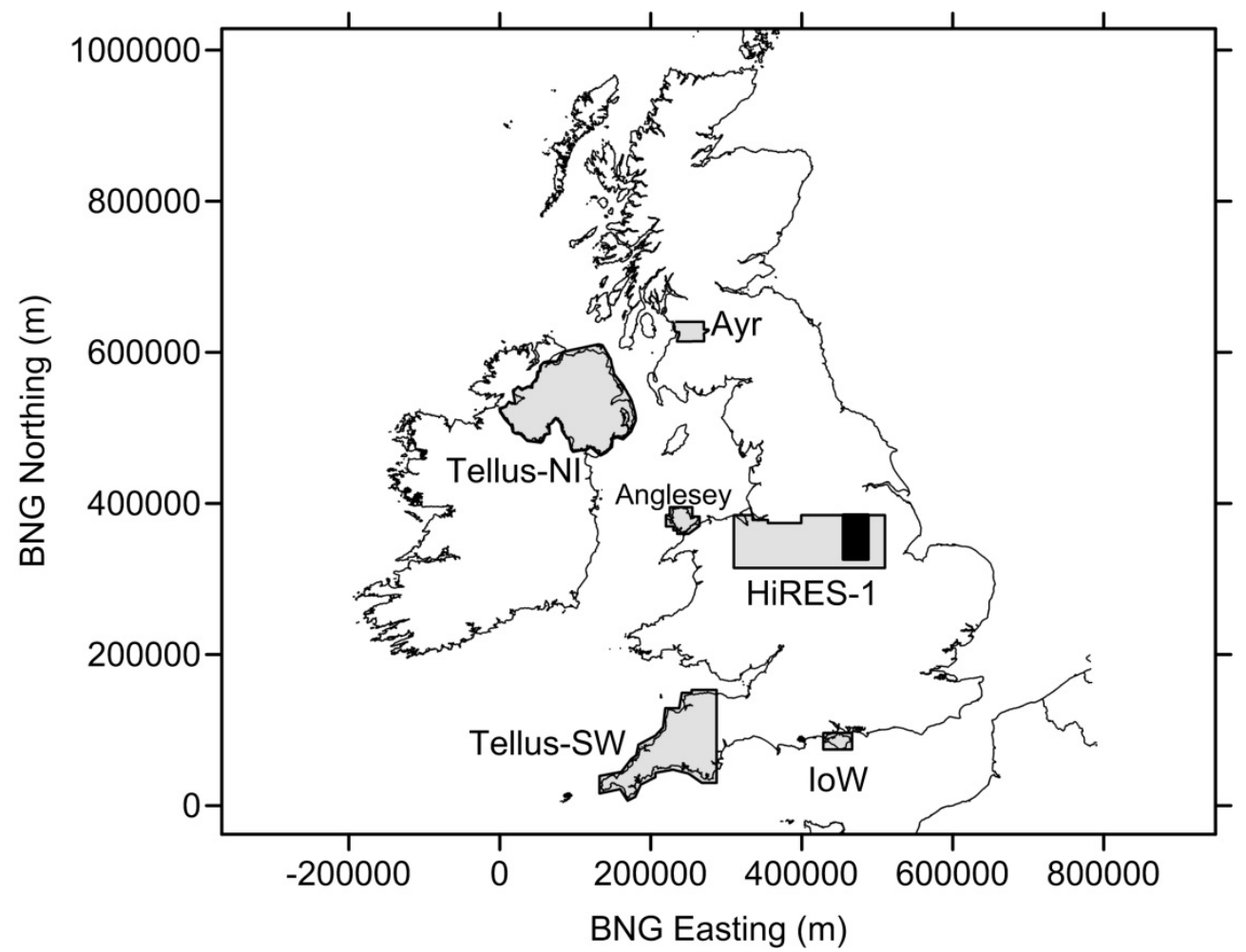

Figure 1. High resolution airborne geophysical surveys conducted in the UK 2008-2013. Six surveys are identified. The black rectangle within the HiRES ${ }^{-1}$ survey is a study area discussed in the text. BNG refers to British National Grid.

References are made by the International Atomic Energy Agency (IAEA, 2010) to a range of previous publications of relevance to the data discussed here. Gamma spectrometry data were historically collected to aid Uranium exploration. The preparation of these data for radioelement baselines, and their application to environmental assessment, is summarised by Tauchid and Grasty (2002); examples of national compilations using airborne, car-borne and ground gamma spectrometry are also provided. Sanderson et al. (2002) also report on international comparisons of such measurements.

There exist a number of comparisons of ground concentration estimates from soil sampling, ground (in-situ) spectrometry and airborne data sets. A set of detailed comparisons across two colliery spoil sites in the UK is presented by Emery et al. (2005b). With no reduction factor applied to the soil sample estimates it was found that the soil sample estimates of Potassium, Thorium and Uranium were persistently higher than the ground estimates. Despite the differences in footprint scale between ground and airborne spectrometry, the studies also indicate good agreement between estimates obtained by the GS and AS methods. Ideally for each airborne observation point, the ground-based measurements should be obtained across the footprint scale of the airborne 
measurement, noting that this is also a non-linear function of distance from the sampled point. One approach, using a hexagonal pattern beneath the centre of an airborne measurement, produced a good correlation between sets of ground (in-situ) and airborne measurements (Tyler, 1994; Sanderson et al., 2002).

Radiometric ground concentrations, typically obtained from the upper $30-50 \mathrm{~cm}$ of the soil (or superficial) profile (see Beamish, 2013), are understood to be derived from the parent bedrock material. In the UK, attenuation zones have been found to be a pervasive feature of the airborne radiometric data sets. Peat soils, in particular, produce readily identifiable attenuation effects. The radiometric data can therefore be used for peat mapping and hence assessments of the lateral extent of the associated carbon store (Beamish, 2014). Although the bedrock provides a specific radiogenic level with associated radiochemical attributes, attenuation of the signal level is controlled by soil moisture content in conjunction with the density and porosity of the soil cover. A valid interpretation model for UK radiometric data, and hence dose values, therefore requires a joint assessment of both soil/superficial and bedrock variations.

The present study is based on data from several high-spatial resolution UK airborne surveys flown since 1998 (Figure 1). Several previous studies have considered the detailed characteristics of radioelement distributions classified by UK subsurface geology (Beamish and White, 2011; Beamish, 2013). Due to the detailed spatial scales involved these are best undertaken on a survey-by-survey basis. The purpose of the present study is to summarise the UK-wide geological associations of observed low and high-value dose rates and to present some local scale effects due to industrial and technological enhancements that have been observed. Case studies of the type of information obtained from the airborne data are presented. Additionally the nature and importance of the attenuating effect of soils, in reducing above-ground exposure levels is theoretically quantified and discussed alongside the results presented. The composite information then represents a limited audit of radiation exposure (AAD) due to terrestrial sources in the UK environment obtained from airborne measurements.

\section{Methodology}

\subsection{Airborne radiometric data}

The six UK surveys flown between 1998 and 2013 are shown in Figure 1. All the surveys were undertaken using a fixed-wing platform and radiometric data were acquired alongside other geophysical measurements The original North Midlands survey (HiRES-1, Fig. 1) of 1998 was largely acquired at lower spatial resolution (400 $\mathrm{m}$ line spacing) and at a higher elevation (90 $\mathrm{m}$ ) than later surveys (typical nominal elevation of $60 \mathrm{~m}$ ). The later surveys all used a line separation of $200 \mathrm{~m}$. The surveys were not targeted at specific science themes (e.g. soil survey), but as a multi-faceted approach to acquiring uniform-quality, modern resource and environmental information.

The surveys shown in Figure 1 typically acquired radiometric data with a 256 channel gamma spectrometer system (e.g. Exploranium GR-820/3) comprising 32 litres of downward-looking Nal(TI) detectors and 8 litres of upward-looking detectors. Full spectrum sampling took place at $1 \mathrm{~s}$ intervals which equates to a distance of 60 to $70 \mathrm{~m}$ along each flight line. Uranium $\left({ }^{238} \mathrm{U}\right)$ is estimated through the radon daughter ${ }^{214} \mathrm{Bi}$ in its decay chain, while Thorium $\left({ }^{232} \mathrm{Th}\right)$ is estimated through ${ }^{208} \mathrm{Tl}$ in its 
decay chain. Potassium $\left({ }^{40} \mathrm{~K}\right)$ is measured directly at $1461 \mathrm{keV}$. Conventionally secular equilibrium in the decay chains of ${ }^{238} \mathrm{U}$ and ${ }^{232} \mathrm{Th}$ (Minty, 1967) is assumed and the ground concentration results are reported as equivalent Uranium (eU) and equivalent Thorium (eTh). A vertically uniform activity concentration is assumed. The standard energy windows used are shown in Table 1.

Table 1. Spectral energy ranges of the airborne radiometric data.

\begin{tabular}{|l|l|l|}
\hline Window & Nuclide & Energy range $(\mathrm{MeV})$ \\
\hline Thorium $(\mathrm{eTh})$ & ${ }^{208} \mathrm{Tl}(2.61 \mathrm{MeV})$ & $2.41-2.81$ \\
\hline Uranium $(\mathrm{eU})$ & ${ }^{214} \mathrm{Bi}(1.76 \mathrm{MeV})$ & $1.66-1.86$ \\
\hline Potassium $(\% \mathrm{~K})$ & ${ }^{40} \mathrm{~K}(1.46 \mathrm{MeV})$ & $1.37-1.57$ \\
\hline
\end{tabular}

The airborne program used well-established guidelines and procedures developed by IAEA (1991, $2003,2010)$. The gamma radiation registered by the detector is composed of contributions from soil/rock, the atmosphere, the aircraft and cosmic radiation. In order to calibrate airborne radiometric data, the commonly adopted standard is to follow the recommendations made in a series of technical documents and publications from the International Atomic Energy Agency (IAEA). The set of procedures applied to all the UK radiometric data are based on protocols described in IAEA (1991) and by Grasty and Minty (1995). The main calibrations performed are:

- Aircraft and cosmic background. A test flight is carried out over the sea at flight elevations from 5000 to $10000 \mathrm{ft}$. Linear regression from the mean counts in each channel and equivalent cosmic channel count rate provides the constant and linear coefficients. The constant represents the background radiation from the aircraft and the linear coefficient is used to calculate the varying part of background radiation due to cosmic radiation.

- Stripping ratios. The stripping ratios are determined prior to each survey using 4 calibration pads (typically $1 \mathrm{~m} \times 1 \mathrm{~m} \times 0.3 \mathrm{~m}$ ). The pads contain known concentrations of the main radioelements, together with a null pad (no radioactive content). Data from each pad are measured for about 10 minutes and the stripping ratios are then calculated.

- Height attenuation. In order to determine height attenuation, test flights are carried out across a test line (about $10 \mathrm{~km}$ in length) typically over a series of heights from 100 to 800 feet. Background and strip corrections are applied and the attenuation is calculated using the logarithmic values of corrected data, and flight altitude. The data are thus corrected to a nominal uniform survey height.

- Radon removal (upward-looking detector method). An additional (upward-looking) crystal pack is used to provide a directional sensitivity and an ability to discriminate between radiation from the atmosphere and from the ground. Atmospheric radon is estimated by summing the window count rates over large time intervals, typically $600 \mathrm{~s}$ in the case of the upward-looking detector method. The calibration requirements for the upward-looking detector method are comprehensively described in IAEA (1991). 
- Conversion to ground concentrations. The 'final' radioelement count rates are converted to ground concentrations using data from a calibration range (often the same range for each survey). The calibration range is a survey line (10 to $15 \mathrm{~km}$ in length) along which known ground concentrations have been established. The procedure determines the ground concentrations that would generate the observed count rates if uniformly distributed in a half-space. The calculation implicitly assumes radioactive equilibrium in the eTh and eU decay series.

Additional client-prescribed QC tests are performed during the course of each survey on a daily or per sortie basis. Examples of these tests and the processing methods applied to the data sets obtained are described by Beamish et al. (2006), White et al. (2009) and Beamish and White (2014).

Flying altitudes, for each individual survey, are a function of the regulatory requirements. Generally 'nominal' survey altitudes have been about $56 \mathrm{~m}$ with a requirement to increase the survey altitude to $200 \mathrm{~m}$ over conurbations. All surveys have used $200 \mathrm{~m}$ separations, although flight line directions have varied to accommodate the magnetic data acquired in conjunction with the radiometric measurements. Nominal flying speeds have typically been between 60 to $70 \mathrm{~m} / \mathrm{s}$.

The ground area, or footprint, which contributes most radioactivity to each $1 \mathrm{~s}$ measurement, was assessed by Duval et al. (1971) and Pitkin and Duval (1980). For a stationary measurement, at a height of $60 \mathrm{~m}, 90 \%$ of the airborne response will be provided from a circle of radius 160 to $180 \mathrm{~m}$ (Kock and Samuelsson, 2011). In practice, for a moving measurement, the footprint will be elliptical and the $90 \%$ contribution area would cover $109,000 \mathrm{~m}^{2}$ (Billings and Hovgaard, 1999). Within that ellipse, the greatest contribution will come from directly beneath the aircraft and will fall off with lateral distance from the flight line. The inherent non-linear form of the sampling across the footprint area poses a challenge when the airborne measurements are compared with ground spectrometer measurements. Additionally, the non-invasive airborne measurements necessarily assume a uniform distribution of radioelements with depth. Due to attenuation, radiometric ground concentration estimates are typically obtained from the upper $30-50 \mathrm{~cm}$ of the soil profile although this varies with material type and water content (Beamish, 2013). In the absence of soil/superficial material transport processes (e.g. erosion) the measurements are considered representative of the parent bedrock material.

\subsection{Dose rate}

The present study uses air absorbed dose (AAD, in units of $n G y \cdot h^{-1}$ ) defined, using the ground concentration estimates, as in IAEA (2010):

$\operatorname{AAD}\left(n G y \cdot h^{-1}\right)=13.078 * \% K+5.675 * e U+2.494 * e T h$

The combined dose measurement therefore covers the energy range from 1.37 to $2.81 \mathrm{MeV}$ and excludes contributions from artificial (man-made) sources. Two of the airborne data sets (Tellus-NI and Ayr, Fig. 1) were previously used (Scheib and Beamish, 2010) to provide a separate assessment of the man-made Caesium $\left({ }^{137} \mathrm{Cs}\right)$ distribution across northern parts of Britain.

The airborne absorbed dose rate values may be converted into units of $\mathrm{Bq} \cdot \mathrm{kg}^{-1}$ if comparison with international and UK legislation is required. A range of radionuclide conversion factors have been 
reported in the literature over the years. Table 2 shows the range of factors found in ICRU (1994), UNSCEAR $(1977,2000)$.

Table 2. Multiplication conversion factors used to convert ground concentrations (AAD) in $n G y \cdot h^{-1}$ to units of radioactivity in Bq. $\mathrm{kg}^{-1}$.

\begin{tabular}{|l|l|}
\hline Radionuclide & Conversion factor (to Bq. $\mathrm{kg}^{-1}$ ) \\
\hline${ }^{40} \mathrm{~K}(\%)$ & 0.0417 to 0.043 \\
\hline${ }^{238} \mathrm{U}(\mathrm{eU}, \mathrm{ppm})$ & 0.427 to 0.462 \\
\hline${ }^{232} \mathrm{Th}(\mathrm{eTh}, \mathrm{ppm})$ & 0.604 to 0.662 \\
\hline
\end{tabular}

As stated in UNSCEAR (2000), to estimate annual effective doses, account must be taken of (a) the conversion coefficient from absorbed dose in air to effective dose and (b) the indoor-outdoor occupancy factor. The average numerical values of those parameters vary with the age of the population and the climate at the location considered. The Committee used $0.7 \mathrm{~Sv}^{-G y^{-1}}$ for the conversion coefficient from absorbed dose in air to effective dose received by adults and 0.8 for the indoor occupancy factor, i.e. the fraction of time spent indoors and outdoors is 0.8 and 0.2 , respectively. The annual effective dose rate (AEDR) in $\mathrm{mSv} \cdot \mathrm{y}^{-1}$ may be calculated from the air absorbed dose rate using the above factors to give:

$\operatorname{AEDR}\left(\mathrm{mSv} \cdot \mathrm{y}^{-1}\right)=\operatorname{DOSE}\left(\mathrm{nGy} \cdot \mathrm{h}^{-1}\right) * 8760(\mathrm{~h}) * 1.0 * 0.7\left(\mathrm{~Sv} \cdot \mathrm{Gy}^{-1}\right) * 10^{-6}$

The factor of 8760 represents the number of hours (h) in a year of 365 days and occupancy of unity has been applied. The conversion means that the airborne dose rate values of 10, 100 and 1000 $\left(n G y . h^{-1}\right.$ ) produce equivalent AEDR estimates of $0.061,0.61$ and $6.1 \mathrm{mSv}$, respectively, for a unitary indoor-outdoor exposure. The worldwide average AEDR is $0.48 \mathrm{mSv}\left(78 \mathrm{nGy} \cdot \mathrm{h}^{-1}\right)$ with the results for individual countries being generally in the range 0.3-0.6 mSv (UNSCEAR, 2000).

\section{Theory}

Terrestrial gamma NORM dose rates largely reflect the variations in the 3 radioelement concentrations associated with geological bedrock lithologies. Thus many airborne radiometric data sets are routinely acquired purely for exploration (e.g. mineral) purposes. It is assumed that the bedrock material acts as a parent to any derived (overlying) superficial (i.e. unconsolidated) sediments and soils. The premise is valid in terms of the texture class of the parent material, defined by the relative proportions of sand, silt and clay, and their associated particle sizes. Soil texture is then also defined, in equivalent terms, for mineral soils.

In the absence of moisture (water), soil, superficial and bedrock materials will have comparable attenuation coefficients at a given source concentration (Carroll, 1981; Løvborg, 1984). Under this condition, the percentage of the gamma ray signal $(S)$ from a particular depth in centimetres (d) is given by:

$S(d)=(1-\exp (-0.046 * \rho * d)) * 100$

where $\rho$ is the dry bulk density of the material in $\mathrm{g} . \mathrm{cm}^{-3}$ (Taylor et al., 2002). This expression is used to indicate that about $90 \%$ of the radiometric signal comes from the top $30 \mathrm{~cm}$ of a soil when the 
average bulk density is $1.6 \mathrm{~g} . \mathrm{cm}^{-3}$. It is then often stated that moisture within the soil increases the attenuation and the attenuation is increased by approximately $1 \%$ (or $10 \%$ ) for each $1 \%$ (or $10 \%$ ) volumetric increase in water content. The statement, which implies a linear relationship, is repeated in many publications e.g. Grasty and Minty (1995), Cook et al. (1996) and IAEA (2003).

Soils are better described as a three-phase system comprising solid, water and air. As noted by Løvborg (1984) and Grasty (1997), any hydrogen supplied to the material as absorbed or free water (e.g. pore water) then generates an additional attenuation (due to scattering) provided by the additional electron content. Following Løvborg (1984) and Grasty (1997), Beamish (2013) calculated and demonstrated the attenuation behaviour of soil material which could be described by dry bulk density, moisture content and porosity. A revised attenuation sensitivity (i.e. the modification of expression (1)) of various generic soil types to the degree of saturation was then evaluated. It was found that the greatest modifications (increases in attenuation) occur in the case of low-density (e.g. organic) soils.

Following that analysis, we note here the behaviour of the additional attenuation sensitivity of the soil material (assumed to be vertically uniform) in relation to that described by equation (1). Figure 2 summarises the flux attenuation behaviour as a function of dry bulk density. The reference level (unity, meaning no change in count rate) is the same material (i.e. material with the same dry bulk density) with no water content. In the analyses, the attenuation behaviour at $10 \%, 25 \%, 75 \%$ and $90 \%$ water saturated materials is shown. The calculations assume a porosity of $20 \%$. Mineral soils typically display a range of dry densities in the range 1.1 to $1.6 \mathrm{~g} . \mathrm{cm}^{-3}$. Organo-mineral soils have densities below this interval with a likely limiting value of 0.1 to $0.03{\mathrm{~g} . \mathrm{cm}^{-3}}^{-3}$ in the case of blanket bog peat (totally organic material). More consolidated materials may provide densities in excess of 2 $\mathrm{g} . \mathrm{cm}^{-3}$, with a typical value for intact limestone being $2.7 \mathrm{~g} . \mathrm{cm}^{-3}$. It can be seen that the mineral soils (arrowed) typically provide an additional $20 \%$ attenuation (a count ratio of 0.8 ) only at high moisture levels.

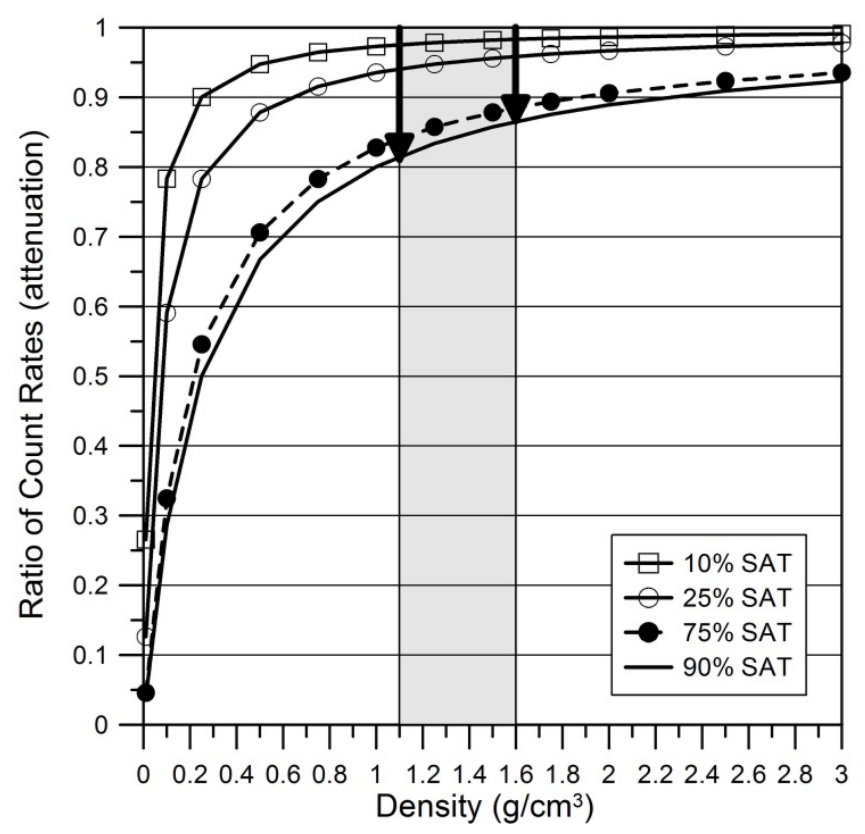

Figure 2. Variation of radiometric attenuation with material dry density for water saturation levels between $10 \%$ and $\mathbf{9 0 \%}$ water saturation. The infilled box notes the typical density range of mineral soils. The reference level of the attenuation (unity) is the attenuation level of dry material of the same density. 
The organo-mineral and organic soils (with densities less than, say, $1 \mathrm{~g} . \mathrm{cm}^{-3}$ ) display an increasing additional attenuation sensitivity with decreasing density. In the limiting case of wet peat attenuation levels increase by $>50 \%$ over their 'dry' equivalents. The behaviour is so distinctive that dose-rate estimates can be used to map peat areas across the UK (Beamish, 2014).

Two particular aspects of attenuation behaviour arise in the case of the UK (i.e. a temperate, midlatitude zone) and these are (a) the prevalence of a 'lower-bound' on soil moisture and (b) the prevalence of organo-mineral and organic soils. UK soil information at the national scale is currently supplied by a soil observatory server (http://mapapps2.bgs.ac.uk/ukso/home.html) and includes estimates of soil moisture in the topsoil $(0-15 \mathrm{~cm})$ layer. The technical background to the estimation is given by Emmett et al. (2010). The lower and upper bounds of the topsoil moisture estimates (across all soil and land-use types) are 16\% and 80\%, respectively, for the 2007 dataset.

There is a wide range of soil-type information available for the UK, and some of the associated descriptive information may include mention of 'wetness' (e.g. permanently wet, seasonally wet, freely draining). Although potentially highly variable, it is suggested that in theoretical studies of radiometric soil attenuation in the UK, a lower bound of $10 \%$ to $20 \%$ moisture content may be considered appropriate. UK soils are characterized by the presence of a wide range of organomineral and loam-type soils. In these soils, typically defined as having $>10 \%$ carbon content, carbon content increases to form other general classifications of organic soil types with 'peat' generally defined as having $>50 \%$ organic content.

The significance of the attenuation behavior described in Figure 2 is that the non-mineral soils will have variable attenuation characteristics that are a function of density (and moisture content) as carbon content changes with soil-type. In-air dose rate estimates are therefore controlled by bedrock lithology in the first instance but are then modified by the variable attenuation inherent to the soil layer. The attenuation depth scale (e.g. the thickness of the soil layer providing $>90 \%$ attenuation) is of the order of $60 \mathrm{~cm}$ for low density mineral soils and wet peat (Beamish, 2013). In order to make use of the attenuation predictions of Figure 2 we would require knowledge of the vertical profiles of density, moisture content and porosity over the same depth scale, or deeper. In practice the lack of knowledge of these parameters over this continuous depth scale (across the UK) is a source of considerable uncertainty.

\section{Results}

The results considered here use data derived from the 6 airborne surveys shown in Figure 1. Each survey provides a spatially-dense radioelement mapping with derived dose rates. An example is first provided using data from the latest (2013) TellusSW survey (Beamish and White, 2014; Beamish et al., 2014). Figure 3a shows a radioelement ternary image formed from the three \%K, eTh and eU contributions. The image is a normalised (to an equal-area histogram) 3-way colour stretching of the contributions from the individual radioelements with red representing Potassium, blue representing Uranium and green representing Thorium. In areas where all three radioelement concentrations are low, the ternary image shows black; when all three concentrations are high, the ternary response 
tends to white. The survey extended offshore to acquire magnetic survey data however it is usual to limit the radiometric image to the coast.
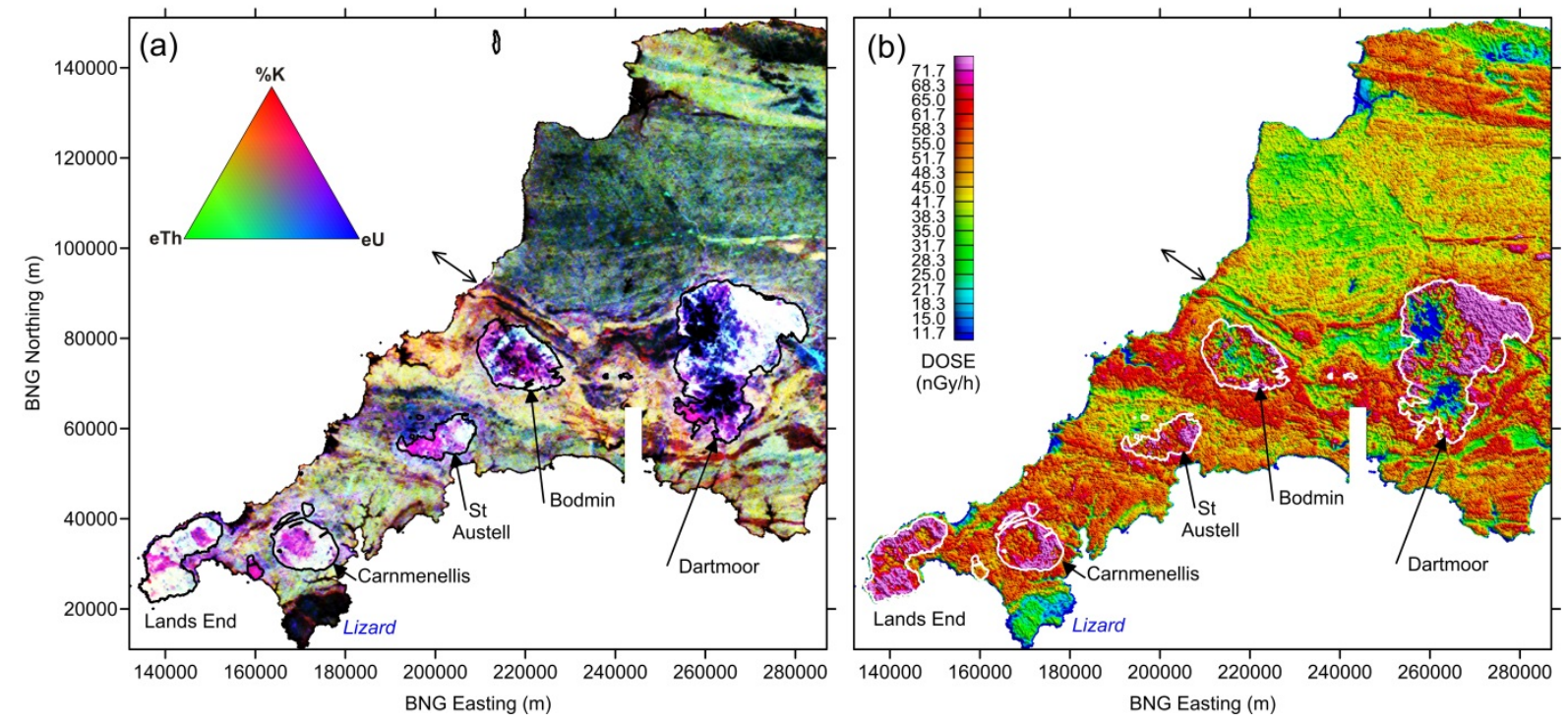

Figure 3. Radiometric survey data obtained from the TellusSW survey (see Fig. 1). Five outcropping Variscan granites are identified and outlined. The double-arrow denotes a transition from Devonian (in the SW) to Carbonifous rocks (in the NE). (a) The ternary colour image obtained using the 3 radioelement ground concentrations. (b) The dose rate values , linear colour scale between 10 and $80 \mathrm{nGy} / \mathrm{h}^{-1}$.

The area contains a series of five outcropping granites and these are outlined and identified in Figure 3. At the regional scale, it can be seen that a major transition in the spectral response (colour) occurs across a geological boundary (double arrow in Fig. 3) separating Devonian rocks to the SW from Carboniferous formations to the NE. The Lizard Complex in the south consists of an overthrust ophiolite (ocean-floor) sequence of rocks and these are clearly defined by a low (black) response. The zones with the highest responses (white colour) are confined to the outcropping granite zones. Within the Bodmin and Dartmoor granites low responses are caused by significant areas of peat formed on the high ground (moors) above the granites. The dose rates calculated from these data are shown in Figure $3 \mathrm{~b}$ using a linear colour scale with high values ( $\left.>80 \mathrm{nGy} \cdot \mathrm{h}^{-1}\right)$ in purple. These are again largely associated with the granite outcrops. At the scale shown, low values can also be observed along some coastal areas and estuaries.

The radiometric data obtained by the airborne surveys are presented here in the form of grids using standard airborne interpolation procedures. The data are typically sampled every 60-70 m along-line but with lines separated at $200 \mathrm{~m}$ intervals. A grid cell size of $40 \mathrm{~m}$ is used in Figure 3. The data sampling is spatially highly regular but anisotropic in the line and cross-line directions. Guidelines for the mapping of radiometric data have been published (IAEA, 2003) and these indicate the most frequently used algorithms are the bi-directional gridding and minimum curvature techniques. Kriging has not been widely used as it is difficult to account for the anisotropy in the sample density when modelling the semivariogram. Here the grids are obtained using a minimum curvature algorithm which produces a smooth grid by iteratively solving a set of difference equations minimizing the total second horizontal derivative while attempting to honor the input data. 
It should be appreciated that the information density of the airborne data sets is high and normally the geophysical information is further classified by bedrock/parent material. The bedrock and superficial dictionaries of UK rock lithologies, at the appropriate scale of 1:50k, are large. Due to the detailed spatial scales involved such analyses are best undertaken on a survey-by-survey basis. Examples of the statistical distributions in the form of normalised histogram and box-whisker assessments of the classified radioelement distributions are presented by Beamish and White (2011) and by Beamish (2013).

\subsection{Airborne Dose rate statistics}

As noted previously, a number of previous studies have considered the detailed characteristics of one or more or all of the individual radioelement distributions classified by UK subsurface geology and soils. The main focus of the present study relates to the UK-wide estimates of dose rates.

\subsubsection{Individual survey statistics}

The airborne data for the 6 UK surveys (Fig. 1) were converted to dose rate values using equation (1). Some computed simple univariate statistics are listed in Table 3. Since water provides a null response (theoretically close to zero for water depths $>1 \mathrm{~m}$ ), the survey data have been cut to the coast prior to the calculations.

Table 3. Dose rate statistics obtained from the 6 UK airborne surveys. Minimum values are 0.01 (an arbitrary low value) since the data have been processed to remove negative values. SD refers to the standard deviation. * this high value spatially coincides with an area of historical mining activity (see later).

\begin{tabular}{|l|l|l|l|l|l|l|l|}
\hline & Year & $\begin{array}{l}\text { N data } \\
\text { points }\end{array}$ & $\begin{array}{l}\text { Area } \\
\left(\mathrm{km}^{2}\right)\end{array}$ & $\begin{array}{l}\text { MAX } \\
\left(\mathrm{nGy} \cdot \mathrm{h}^{-1}\right)\end{array}$ & $\begin{array}{l}\text { Median } \\
\left(\mathrm{nGy} \cdot \mathrm{h}^{-1}\right)\end{array}$ & $\begin{array}{l}\text { SD } \\
\left(\mathrm{nGy} \cdot \mathrm{h}^{-1}\right)\end{array}$ & $\begin{array}{l}3^{\text {rd }} \text { quartile } \\
\left(\mathrm{nGy} \cdot \mathrm{h}^{-1}\right)\end{array}$ \\
\hline Anglesey & 2009 & 72,590 & 1198 & 98.04 & 35.21 & 9.96 & 40.75 \\
\hline Ayr & 2004 & 81,125 & 977 & 83.49 & 23.05 & 11.04 & 27.54 \\
\hline HiRES-1 & 1998 & 658,394 & 13,408 & 254.79 & 38.86 & 13.32 & 47.44 \\
\hline IoW & 2008 & 34,973 & 836 & 61.50 & 28.48 & 9.48 & 34.87 \\
\hline TellusNI & $2005-6$ & $1,151,734$ & 16,089 & 320.11 & 33.98 & 22.57 & 48.45 \\
\hline TellusSW & 2013 & 685,722 & 10,929 & $579.15^{*}$ & 47.87 & 14.69 & 56.46 \\
\hline
\end{tabular}



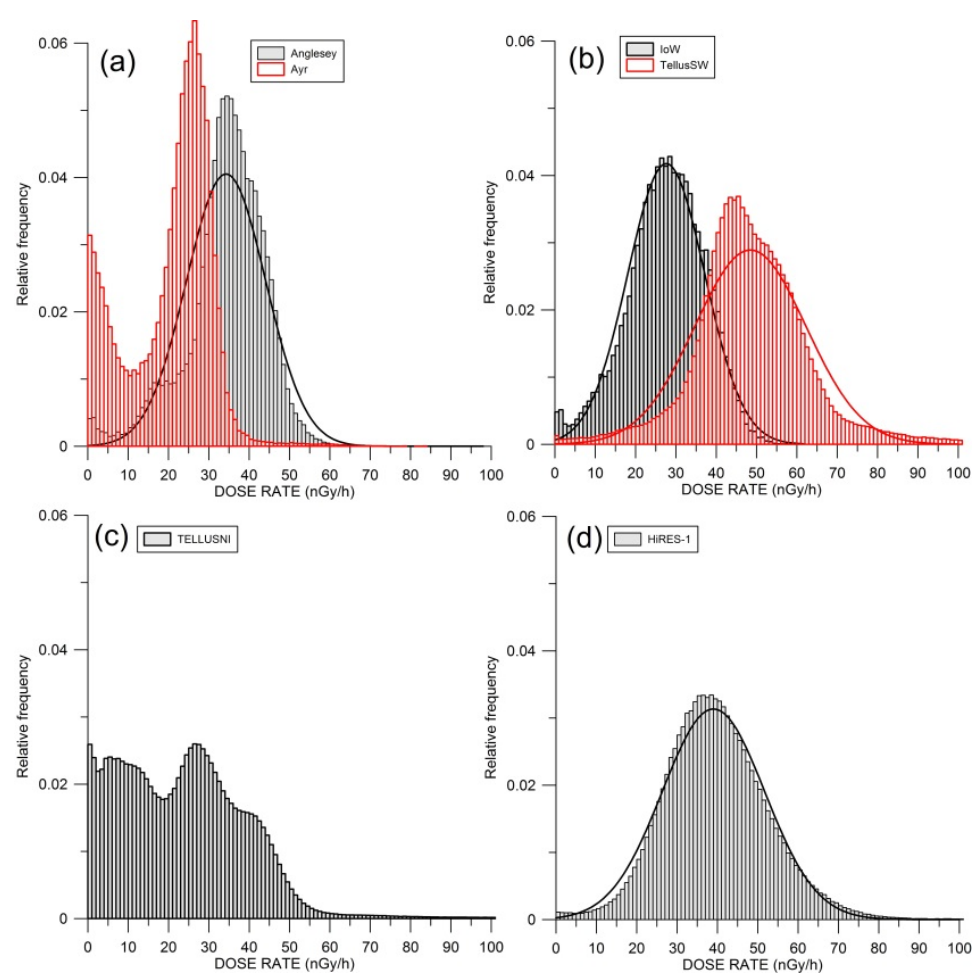

Figure 4. Normalised histograms of the six whole-survey dose rate estimates listed in Table 3. (a) Anglesey and Ayr. (b) IoW and TellusSW. (c) TellusNI and (d) HiRES-1.

Median central moments of the distributions range from 23.05 to $47.27 \mathrm{nGy} \cdot \mathrm{h}^{-1}$ but care must be taken into account when interpreting these 'whole survey' values. The individual distributions of the dose rate values are in some cases complex. It can be noted that no one simple parametric model (e.g. a normal or log-normal distribution) can be assumed. Figure 4 shows the normalised histogram distributions of the data sets summarised in Table 3. Where appropriate, the best-fitting normal distribution is also shown. Of the 6 distributions shown, only the loW (Fig. 4b) and HiRES-1 (Fig. 4d) distributions resemble normal behaviour. A number of highly-peaked distributions are evident in Figures 4a,b. Additional low value (e.g. $<5 \mathrm{nGy} \cdot \mathrm{h}^{-1}$ ) increases are observed in the case of the Anglesey and Ayr data (Fig. 4a), the loW data (Fig. 4b) and the TellusNI data (Fig. 4c). The TellusNI data (Fig. 4c) form a clear multi-mode distribution that requires further bedrock/soil classification. A component of the low value behaviour in both the Ayr (Fig. 4a) and TellusNI (Fig. 4c) data is due to the percentage of blanket peat encountered. The Ayr survey data is further described later and the bedrock/soil classifications of the TellusNI data set are described by Beamish (2013).

Similar behaviour is observed in geologically classified subsets of the data (Beamish and White, 2011; Beamish, 2013). The majority of surveys are coastal (Fig. 1) and the distributions contain contributions from a number of water bodies (estuaries, lakes and reservoirs). The null water responses increase the low value tail entries within all the distributions. A number of data sets record negative values due to the statistical nature of the measurement when applied to low (e.g. theoretically zero) signal levels. Such values, typically obtained over water bodies, may be removed by processing techniques which, for example, replace the negative value with the 'nearestneighbour' non-negative value. 
The distributions obtained by the analysis necessarily reflect the range of radioactivity levels encountered in the geological (and soil) formations sampled by each survey. The fifth edition 1:625,000 (1:625k) scale bedrock geological map of the United Kingdom was released as DiGMapGB625 in 2008 (BGS, 2008). The data are described by Smith (2011) and further details can found at http://www.bgs.ac.uk/products/digitalmaps/digmapgb 625.html. The lexicon comprises 86 lithological classifications and 244 standard lithostratigraphic assignments. In terms of general bedrock lithological assessments, the radiometric data considered here provide a $>87 \%$ coverage of the UK bedrock formations. Major bedrock lithologies from the Cambrian through to the Paleogene are represented in the analysis.

Table 3 indicates maximum dose values ranging from a low value of $61.5 \mathrm{nGy} \cdot \mathrm{h}^{-1}$ (loW survey) to a high value of $579.1 \mathrm{nGy} \cdot \mathrm{h}^{-1}$ (TellusSW survey). The latter high value is a contribution from a TECHNORM locality that is discussed in more detail later. When this localised contribution is removed, the maximum value reduces to $155 \mathrm{nGy} \cdot \mathrm{h}^{-1}$. The loW survey provided the first modern radiometric survey across the geological formations that characterise much of southern England. The low maximum value is spatially associated with the young Paleogene and Cretaceous formations encountered (Beamish and White, 2011). The Ayr survey data is biased to low values by a large areal extent of peat, as discussed later.

\subsubsection{Granitic terrains}

Within the survey areas, granitic terrains generate the highest spatially-extensive levels of radioactivity observed in the data sets. The TellusNI survey contains the Mourne Mountain intrusive body, while the TellusSW survey contains a series of five outcropping granites which are components of the underlying Cornubian batholith (see Fig. 3). The young Mourne Mountains complex is Paleogene ( $56 \mathrm{Ma}$ ) in age and consists of a complex of 5 principal biotite-type intrusions. The much older granites of SW England are more extensive, outcropping above a deep batholith, and were emplaced following the Variscan orogeny (290 Ma).

Dose rates for individual Variscan granites from the Tellus-SW survey, and the Mourne complex, have been assessed by isolating the data across the individual outcrops. The data are summarised in Table 4.

Table 4. Dose rate statistics obtained from outcropping granite areas. SD refers to the standard deviation. The first 5 entries are granites in SW England (see Fig. 3). The final entry is from Northern Ireland.

\begin{tabular}{|l|l|l|l|l|l|l|l|}
\hline & $\begin{array}{l}\text { N data } \\
\text { points }\end{array}$ & $\begin{array}{l}\text { Area } \\
\left(\mathrm{km}^{2}\right)\end{array}$ & $\begin{array}{l}\text { Min } \\
\left(\mathrm{nGy} \cdot \mathrm{h}^{-1}\right)\end{array}$ & $\begin{array}{l}\text { Max } \\
\left(\mathrm{nGy} \cdot \mathrm{h}^{-1}\right)\end{array}$ & $\begin{array}{l}\text { Median } \\
\left(\mathrm{nGy} \cdot \mathrm{h}^{-1}\right)\end{array}$ & $\begin{array}{l}\text { SD } \\
\left(\mathrm{nGy} \cdot \mathrm{h}^{-1}\right)\end{array}$ & $\begin{array}{l}3^{\text {rd }} \text { quartile } \\
\left(\mathrm{nGy} \cdot \mathrm{h}^{-1}\right)\end{array}$ \\
\hline Bodmin & 15422 & 203 & -0.37 & 110.6 & 52.69 & 18.46 & 64.87 \\
\hline Carnmenellis & 9522 & 128 & 8.96 & 144.2 & 66.09 & 11.05 & 73.27 \\
\hline Dartmoor & 48494 & 625 & 0.01 & 153.95 & 58.29 & 29.59 & 81.66 \\
\hline Land's End & 13541 & 181 & 22.4 & 141.05 & 72.33 & 13.04 & 80.5 \\
\hline St Austell & 6997 & 91 & 17.27 & 128.65 & 62.41 & 13.68 & 72.8 \\
\hline Mourne & 11619 & 144 & 3.59 & 320.1 & 124.7 & 44.7 & 150.8 \\
\hline
\end{tabular}

It is very evident from the median values noted in Table 4 that the young Mourne granite complex is a factor of 2 more radiogenic than the older Variscan granites of SW England. 


\subsection{Geology and Dose rates}

Geological controls on the radon potential in England, based on indoor radon measurements, have been recently discussed by Scheib et al. (2013). Some of the geological units associated with high radon potential are well known, such as the granite intrusions noted above, the Carboniferous limestones of Derbyshire and the Jurassic ironstones of central England. High dose rate values are often associated with these same geological formations. It is relatively straightforward to isolate high dose values within the airborne data sets and then investigate their geological (e.g. NORM) or environmental (e.g. TENORM) attributes. The maximum contributions obtained from the surveys are included in Tables 3 and 4 and the statistical results reflect both potential contributions.

\subsubsection{An example of the HIRES-1 area}

Within the large HiRES-1 data set (area of $13,408 \mathrm{~km}^{2}$ ) only $89 \mathrm{~km}^{2}(0.7 \%$ of the total area) is associated with dose values $>50 \mathrm{nGy} \cdot \mathrm{h}^{-1}$. The most spatially extensive high dose rates are obtained within a section of the Mercia Mudstone Group (Triassic argillaceous mudstones) that extends from NE Nottingham northwards. Their spatial distribution is shown in Figure 5 across a $33 \times 59 \mathrm{~km}$ rectangle. Figure 5 a shows a ternary image of the radioelement concentrations.

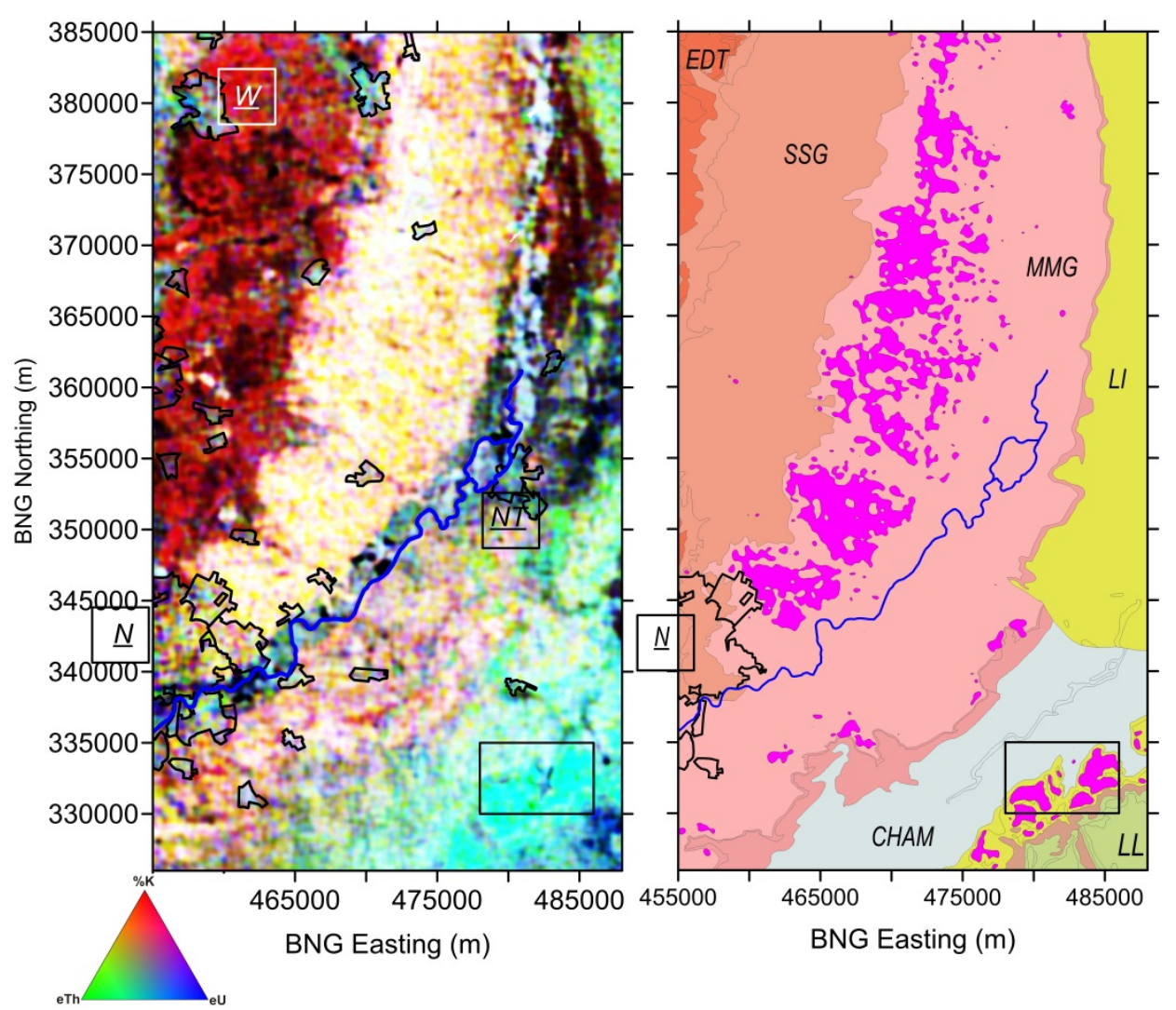

Figure 5. A 33 x $59 \mathrm{~km}$ rectangle across eastern England, see Figure 1 for location. (a) Radiometric data from the HiRES-1 survey shown as a ternary colour image (a 3-way colour stretch of the Potassium, Thorium and Uranium components) of the data. Black polygons identify the largest conurbations. W: Worksop, N: Nottingham, NT: Newark on Trent. (b) High values (> $50 \mathrm{nGy} \cdot \mathrm{h}^{-1}$ ) of DOSE rate shown in purple on background 1:250k bedrock geological map. EDT: Edlington Formation. SSG: Sherwood Sandstone Group. MMG: Mercia Mudstone Group. LI: Lias Group rocks. CHAM: Charnmouth Mudstone. LL: Lincolnshire Limestone. The river Trent is identified as a heavy blue line. The $5 \times 8 \mathrm{~km}$ rectangle in the SE is an area of Ironstone discussed in the text. 
The geological units (1:250k scale) across the area are shown in Figure $5 \mathrm{~b}$ and are centred on the Mercia Mudstone Group (MMG) rocks. The formations range in age from the Permian in the northwest (EDT, the argillaceous Edlington Formation) through to the Jurassic in the east (LI) and southeast ( $\mathrm{LL}$ and $\mathrm{LI}$, the argillaceous Lias Group rocks). At the scale shown, the radioelements indicate a broad correlation with the main bedrock units which is most evident in the Potassium rich Sherwood Sandstone Group rocks (SSG). Within each formation there is a considerable amount of detailed variation and complexity. The western portion of the MMG shows a broad high value response (yellow to white) indicating a high equalised Thorium-Potassium response. This character is modified along a clear zone associated with the Trent River valley, identified in Figure 5. These responses are connected with fluvial and possibly fluvial-glacial deposits within the superficial materials. In detail, the data map a series of paleochannels of the river system and the large and persistent width of the zone indicates the high energy of former processes. A series of polygons in Figure 5a identify the larger urban areas, the largest of which is Nottingham ( $\mathrm{N}$ in Figure 5 ).

Zones with dose rates $>50 \mathrm{nGy} \cdot \mathrm{h}^{-1}$ are identified in relation to the geological formations in Figure $5 \mathrm{~b}$. To the north of the Jurassic CHAM formation there is an almost exclusive association of high values with the western part of the MMG formation. The relationship does not appear to have been previously noted in relation to UK dose rate values (AAD). The source of the high values relates to specific clay lithologies within the MMG group which are known, from deep borehole logs (Howard et al. (2009), to have high total counts. The $5 \times 8 \mathrm{~km}$ rectangle in Figure 5 defines an area containing a sub-group of the Lias group rocks. The area is centred on the Vale of Belvoir and the high value dose values are largely confined to the Marlestone rock formation (Ironstone). As can be seen in Figure $5 a$, the response is Thorium dominated. The Ironstone formation has been particularly well studied in relation to radon exposure (Hodgkinson et al. 2006; Scheib et al., 2013).

Other high value AAD zones within the HiRES-1 data set are much smaller and geologically diverse. Elevated values associated with the Carboniferous 'reef' limestone in Derbyshire although generally high (see Lahti and Jones, 2003), show peak values of $>60 \mathrm{nGy} \cdot \mathrm{h}^{-1}$ in a well-defined, localised zone some $2 \mathrm{~km}$ to the west of the town Castleton. The high response is Uranium dominated. Localised high (e.g. > 50 units) AAD values due to TENORM are far less evident in this large data set. This may be partially due to the wide line spacing used. Three of the more readily identified TENORM types occurring in the data set are concentrations due to (1) colliery spoil (Emery et al., 2005b), power station fly-ash (Kestell, 2000) and iron-ore mines and processing plants (Lahti and Jones, 2003).

\subsection{Soil attenuation}

Despite the general predominance of the bedrock signal in the AAD values, detailed analysis of the airborne data sets has, however, revealed the extent and variability of the attenuation of the radiometric signal by the soil cover. UK soil information at the national scale is currently supplied by a soil observatory server (http://mapapps2.bgs.ac.uk/ukso/home.html). This information is used, whenever possible, when considering site-specific soil information in relation to the airborne data.

\subsubsection{The example of the Ayr Survey}

The Ayrshire survey of 2004 (Fig. 1) was contained within a main rectangle of 41 by $26 \mathrm{~km}$. Lines were flown E-W at $200 \mathrm{~m}$ intervals. An eastward extension was flown to assess the industrial legacy responses across the Muirkirk valley. In the west, the coastal zone associated with the town of Ayr 
was omitted. The dose data obtained are shown in Figure 6a using a linear colour scale. Three conurbations, Irvine, Kilmarnock and Troon are identified together with the central location of the Mauchline Sandstone Formation (MSF) basin and perimeter volcanic formation. The formation can be seen to influence (reduce) the level of the radiometric signal observed. The most striking feature of the data are the attenuation zones (black responses) observed predominantly in the east of the area.

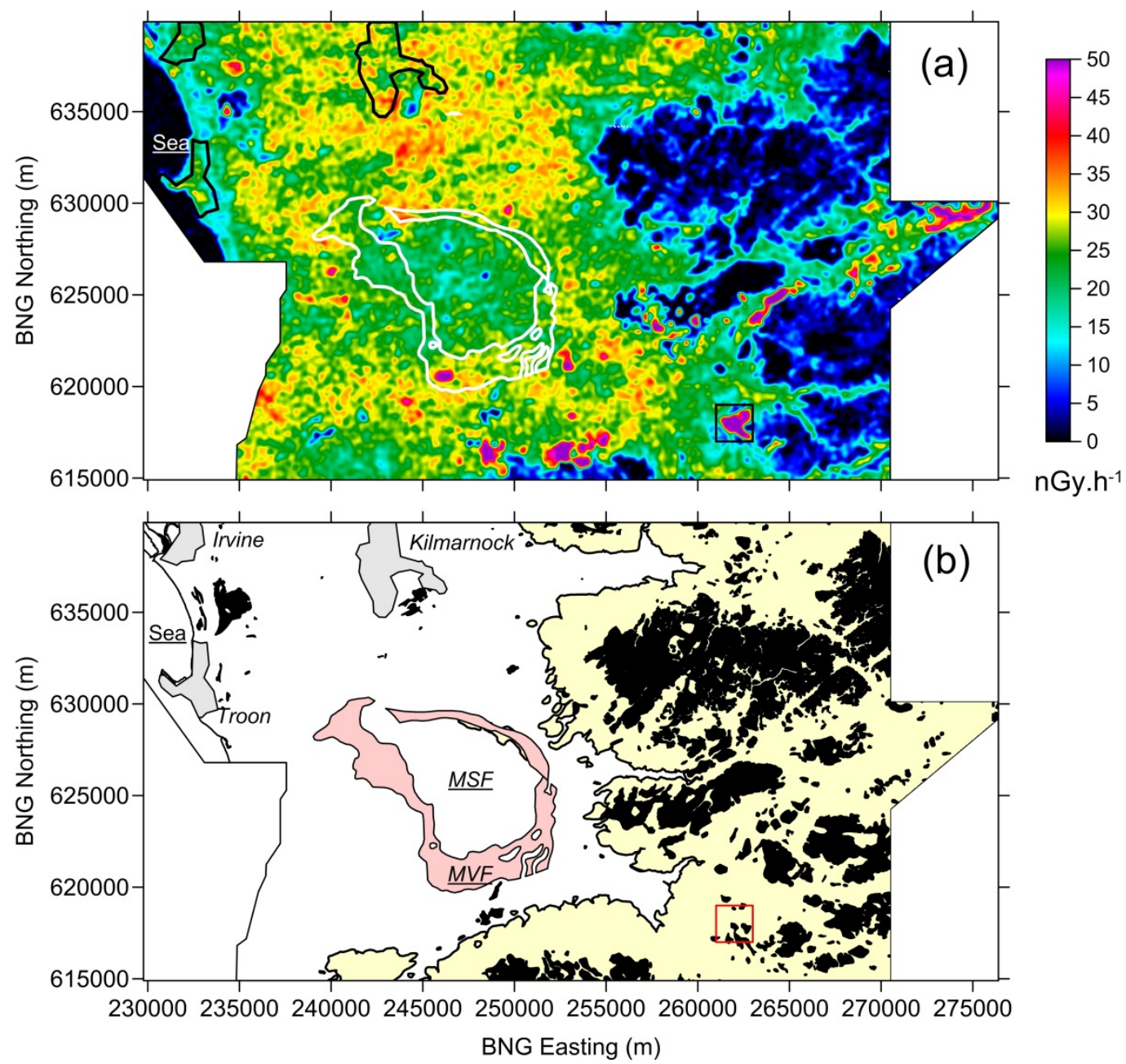

Figure 6. . (a) Radiometric dose data from the Ayrshire survey shown as a continuous colour plot. Geological line work in white. (b) Areas of peat defined by DiGMAPGB50 mapping of peat (zones in black). Infilled area (in the south and east) defines elevations greater than $160 \mathrm{~m}$. Geological line work: MSF (Mauchline Sandstone Formation), MVF (Mauchline Volcanic Formation). Black rectangle is a $2 \times 2 \mathrm{~km}$ area containg an opencast coal mine, that is used for a more detailed study. Polygons with grey infill denote main conurbations.

The BGS 1:50k superficial deposit mapping of peat locations are identified by black zones in Figure $6 \mathrm{~b}$ and can be seen to be largely, but not exclusively, concentrated on the high ground in the east. Ground above $160 \mathrm{~m}$ is identified by light infill. At the broad scale there is clearly a high degree of correspondence between the low value (dark) areas of Figure 6a and the peat locations of Figure $6 \mathrm{~b}$.

A number of localised but extensive zones of high dose values (>50 nGy. $\mathrm{h}^{-1}$ ) are observed in Figure $6 a$. These are associated with a series of opencast coal mines that occur across the area, particularly in the south and east. Some of the recent workings may be associated with older ( $19^{\text {th }}$ century) 
colliery sites and mineral concentrations may occur in various mine spoil zones. The high value zones would normally be identified as TENORM concentrations and so the numerous high value anomalies have been investigated in further detail. Figure 7 considers a $2 \times 2 \mathrm{~km}$ rectangle containing the Garleffan opencast coal working (identified in Fig. 6). Significantly, the site contains no former coal workings. Figure 7a shows an aerial view of the site and it should be noted that the body of water postdates the survey of 2004 . The survey data sampling ( $200 \mathrm{~m}, \mathrm{E}-\mathrm{W}$ survey lines) is indicated by dots. The main excavation pit is defined by a series of white contours (10 $\mathrm{m}$ intervals) that show the $45 \mathrm{~m}$ deep opencast depression in the centre of the image. The colour contours of the dose rate shown in Figure $7 \mathrm{~b}$ clearly identify the opencast site with enhanced values $>50 \mathrm{nGy} \cdot \mathrm{h}^{-1}$, locally extending to $70 \mathrm{nGy} \cdot \mathrm{h}^{-1}$.
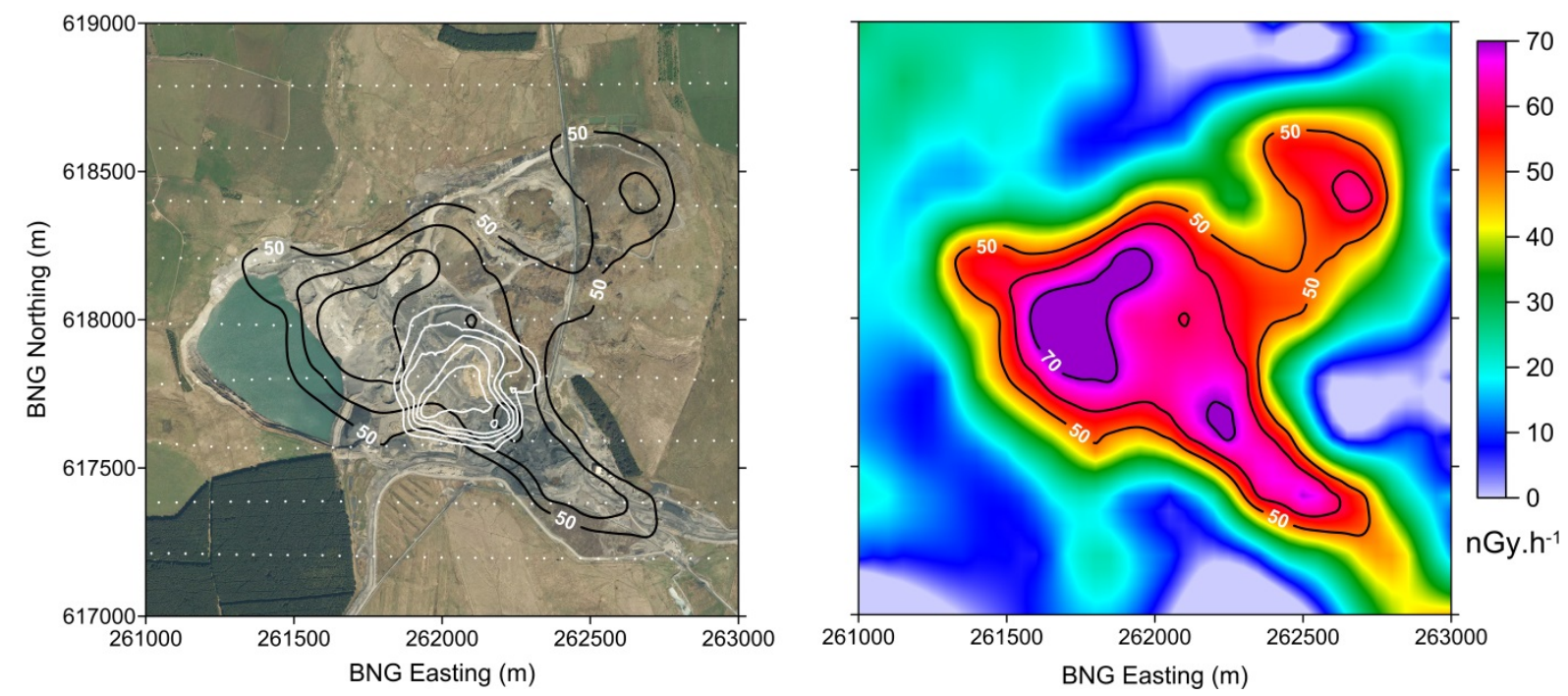

Figure 7. A 2x2 km study area centered on the Garleffan opencast coal working (also referred to in Fig. 4). (a) aeriel photograph (recent) and depth contours of main opencast depression (in white). Black contours denote dose values. White dotes denote airborne sampling. It should be noted that the body of water postdates the survey data. (b) Radiometric dose data shown as a continuous colour plot and as black contours.

Apart from some small areas in the west, the site is underlain by the Strathclyde Group coal measures. Since the bedrock across the main anomaly is continuous beyond the site, it appears that the enhanced values must be related to near-surface conditions. It is not possible to rule-out enhanced concentrations of radiogenic materials across the anomaly zone, however the main material constituent responsible for the radiogenic level (the parent bedrock) is uniform across the site. It is therefore possible that the enhanced values are wholly/partly associated with zones of thin or absent soils. The potential absence of soil moisture, and thus attenuation, could contribute to the observed behaviour. Without further ground control, the two competing hypotheses cannot be tested.

\subsubsection{A case study from the Anglesey survey}

In order to further investigate soil related effects on observed exposure levels, an area with a soil 'hole' (an absence of soil) but with no associated mineral/material processing context was selected. Figure 8a shows a $4 \times 3 \mathrm{~km}$ area centred on a military airfield on Anglesey (see Fig. 1). RAF Valley, opened in 1941 and has 6 runways. The military site has a well-defined perimeter in relation to the landscape. Three soil types are identified in Figure 8a. In the north the unit labelled SP identifies slowly permeable, seasonally-wet, acid loamy and clayey soils. The central soil unit which contains 
the military base is identified as a sand-dune soil. A small unit of freely draining, slightly acid loamy soil (FD) is identified on the eastern margin. Two water bodies and the sea are also identified. An estuary, with sandbanks, is located in the NW of the area.

The bedrock across the site comprises two geological formations. The contact is identified by the dotted line which separates the New Harbour schists (Neoproterozoic) in the west from the Ogwen Group conglomerate (Ordovician) in the east. Superficial deposits largely follow the form of the soil map with blown sand underlying the sand-dune soils and a till-diamicton layer elsewhere.

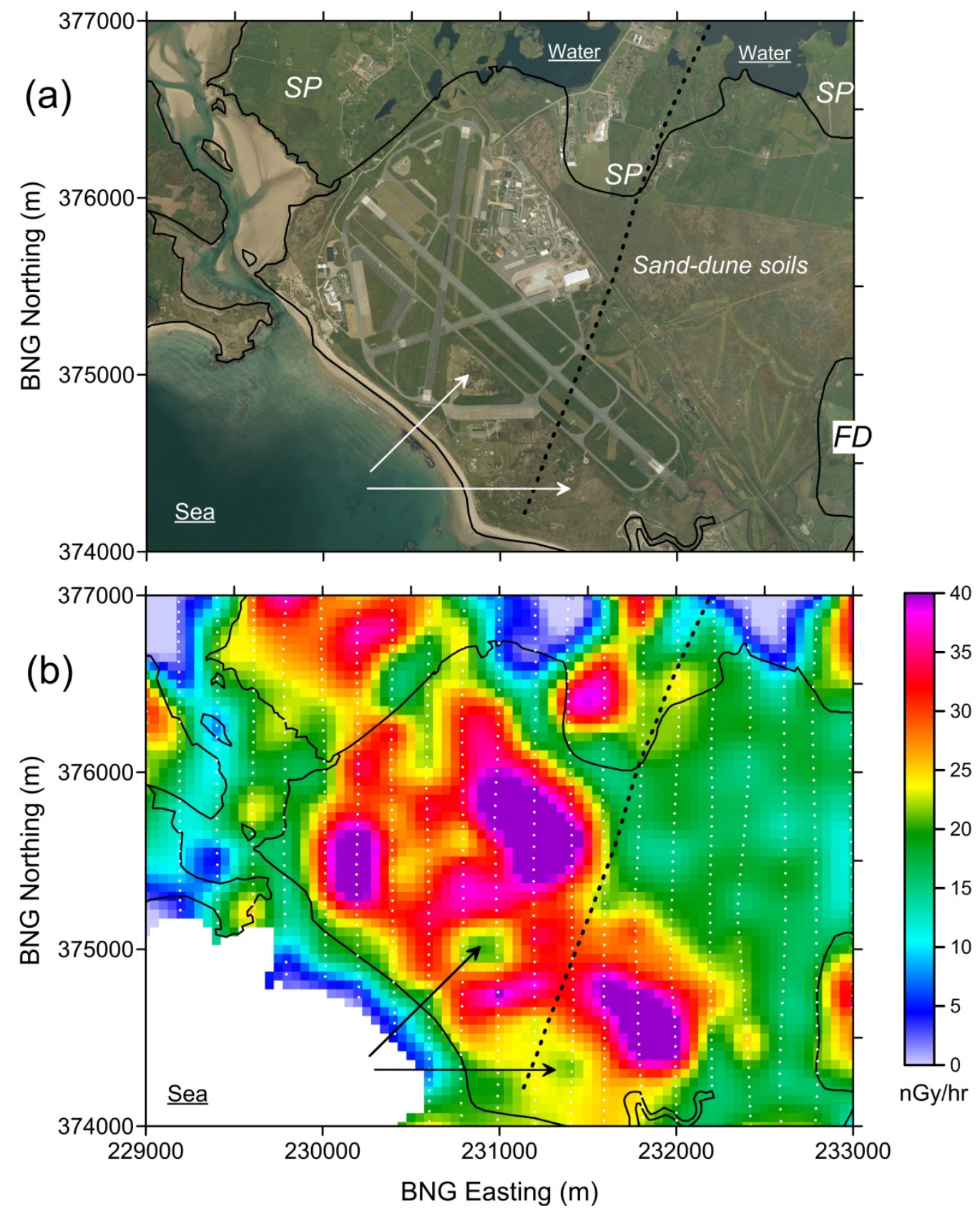

Figure 8. A $4 \times 3 \mathrm{~km}$ control study area across the RAF Valley base on Anglesey. (a) ariel photograph with soil units identified with black lines. SP: slowly permeable, seasonally-wet, acid loamy and clayey soils, FD: freely draining, slightly acid loamy soil. Dash line identifies a bedrock contact. (b) Radiometric dose data shown as a continuous colour plot. White dots are airborne data sampling points. 
The dose rate values obtained by the Anglesey survey are shown in Figure 8b. The spatial distribution shows no relation to the simple form of the bedrock. Instead, a variety of effects are observed that appear to partially correlate with the soil distribution. In the north, the SP soil unit displays dose rate values $>25 \mathrm{nGy} \cdot \mathrm{h}^{-1}$ and attenuation effects across the two water bodies are evident. Equally the small area of FD soils shows a similar enhancement. The main unit of sand-dune soils displays mid-range values of 10-20 nGy. $\mathrm{h}^{-1}$ across most of the area in the east. Within the area of the base, however, average values exceed $30 \mathrm{nGy} \cdot \mathrm{h}^{-1}$ and, locally, values exceed $40 \mathrm{nGy} \cdot \mathrm{h}^{-1}$ in 3 zones, two of which coincide with areas of built structures. There is no reason to suppose that the base/runway construction involved materials with a high radiogenic content and so the variations observed seem to be more reasonably explained by variations in reduced near-surface attenuation. The high values associated with the interior of the base would then be attributable to lack of free or absorbed water in the upper $30-50 \mathrm{~cm}$ of the surface. It is possible, however, that the structures and buildings contribute to the increased dose rate. Without further ground control, the two competing hypotheses cannot be tested. Within the base, two areas of increased attenuation which provide values close to those of the sand-dune soils are arrowed.

In broad terms it is suggested that both ground-based GS measurements, (typical elevation of $1 \mathrm{~m}$ ) and airborne radiometric survey AS measurements (typical elevation of $>60 \mathrm{~m}$ ) are subject to attenuation effects linked directly to soil water and density content and enhanced count rates in the absence of soil cover. It should be noted that, in both cases, the air absorbed dose rates are correctly determined in terms of exposure (in air) to emissions.

\subsection{Comparison of soil sample (SS) and airborne survey (AS) dose rates}

Soil activity concentrations, across most areas of the UK, have been derived from an extensive and systematic geochemical soil and stream water survey (referred to as G-Base, Johnson and Breward, 2004; Johnson et al., 2005). The TellusNI survey (Fig. 1) involved both airborne geophysical and ground geochemical sampling. The methods used in the geochemical mapping are described by Smyth (2007). The soil sampling of rural areas and selected urban areas provided 6,862 samples at an average density of 1 site per $2 \mathrm{~km}^{2}$. Here we consider the top soil data samples from $5-20 \mathrm{~cm}$. The laboratory XRF analyses provided a standard suite of geochemical analyses including \% $\mathrm{K}$, eTh $(\mathrm{ppm})$ and eU (ppm). These were converted to dose rate using equation (1); with attenuation effects not taken into account, these are dose rates 'in-soil'. In order to undertake a comparison of the airborne and soil data sets, the geochemical sampling point locations were buffered by circles with radii ranging from 100 to $500 \mathrm{~m}$. The statistical behaviour of the airborne estimates falling within these zones was then examined. It was found that a buffer radius of $250 \mathrm{~m}$ provided between 11 and 26 airborne estimates per geochemical sampling zone. The median values of the airborne estimates were then calculated. It was found, as expected, that for each of the individual radioelements, the subsurface soil sample estimates exceeded those of the airborne estimates. This behaviour is repeated in equivalent analyses conducted for the UK airborne data sets but not reported here.

A comparison of the individual radionuclide and the derived dose rate estimates is shown in Figure 9. The expectation of perfect correlation is shown by the dash lines. It is evident that a quasi-linear relationship exists between the soil and airborne estimates in all cases. It is also evident that persistently higher soil dose values are observed. The bias offset between the 2 sets of dose rate estimates is between 10 and $15 \mathrm{nGy} \cdot \mathrm{h}^{-1}$. In order to make a valid 'in-air' dose rate comparison it would be necessary to take into account the depth dependence of the soil sample contributions, and 
hence attenuation, to the surface (in-air) flux. As has already been noted, the subsurface attenuation is largely controlled by soil moisture content in conjunction with the density and porosity of the soil cover. The precise reduction factor to use to correct subsurface estimates to 'in-air' equivalent estimates is very difficult to establish given the range of soil types, densities and wetness levels encountered in studies of this type. It is worth noting that in summaries of population-wide exposure levels, spectrometric analyses of soil samples are generally used (UNSCEAR, 2000).
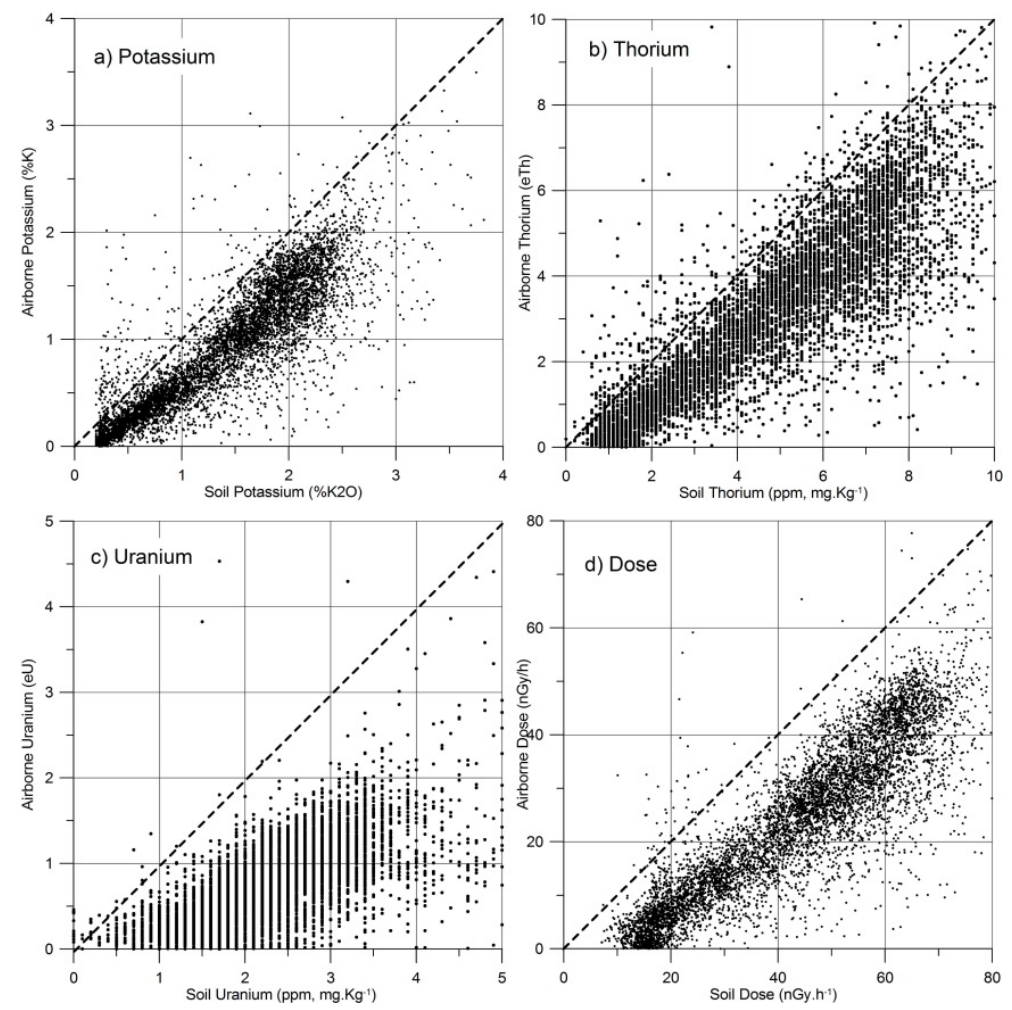

Figure 9. Comparison of soil sample and colocated airborne radiometric data for the TellusNI data set (6862 samples). (a) Potassium (\%K). (b) Thorium (eTh). (c) Uranium (eU). (d) dose rate (nGy. $h^{-1}$ ).

The results obtained might be construed as a systematic calibration issue with one (or both) datasets. An independent ground investigation of the $\mathrm{NI}$ airborne data set was undertaken in September 2007 by the Stirling University Environmental Radioactivity Laboratory. The measurements included soil core sampling (and subsequent laboratory analysis) and ground (GS) measurements along profiles. One of the specific aims was to investigate the calibration of the airborne Caesium estimates and these are discussed by Scheib and Beamish (2010) and Rawlins et al. (2011). The GS natural radioelement series results at 80 calibration locations were also compared with the core and airborne measurements (using the airborne results at the nearest location). A detailed mean and variance analysis of the correspondence between $\% \mathrm{~K}, \mathrm{eTh}$ and eU estimates was performed using the three sets of estimates (core analysis, GS and AS). The contribution from depth to the surface gamma rate flux had to be assessed for each of the radioelements in order to compare the subsurface core estimates with those of the 'in-air' GS and AS measurements. As noted in Section 3, the attenuation calculation requires knowledge of the bulk density, moisture content and porosity over the appropriate depth interval. In practice, simple weighting schemes are applied and in this case, the core sample estimates were weighted by 0.6 for the $0-10 \mathrm{~cm}$ contribution, 0.3 
for the $10-20 \mathrm{~cm}$ contribution and 0.1 for the $>20 \mathrm{~cm}$ contribution. Despite this simplification, the AS measurements were found to be in good agreement with the soil core data.

\subsection{TENORM contributions}

Some of the larger scale TENORM airborne observations of high dose rates have already been noted. It is also worth recording the site-scale detail provided by some of the survey data in relation to radioactivity in the UK environment. In part this relates to the often complex legacy contributions, accumulated over that last centuries, of former land-use activities. Here we focus on just two locations although the data sets have revealed a wealth of effects.

\subsubsection{Industrial legacy}

Figure 10 shows a $5 \times 5 \mathrm{~km}$ coastal survey area that was undertaken on the western margin of the Ayr survey (Fig. 1). The survey used a detailed $50 \mathrm{~m}$ (N-S) line-separation that provides a $10 \mathrm{~m}$ grid of dose rate values from 8788 observations. Flight elevations were largely $56 \mathrm{~m}$ except in the extreme NW corner and across the main conurbation in the east (here elevations generally exceed $120 \mathrm{~m}$ and extend to $200 \mathrm{~m}$ ). The industrial site considered is complex with activities of historical coal-mining, industrial processing (e.g. iron and chlorine production) and munitions production (the Nobel works). The site is largely underlain by bedrock of the Carboniferous coal measures interspersed with some lavas and basic intrusions. Overlaid on the topographic map are contours showing dose rate values in excess of $35 \mathrm{nGy} \cdot \mathrm{h}^{-1}$. While the dose threshold applied is not particularly high, the data reveal a variety of features at the small scale and more extensive high value zones in the NW. The results have been studied using current and historical maps dating back to 1860. A set of features are labelled $A$ to $I$ in Figure 8 . Feature $A$ is a former landfill site co-located on the site of an earlier coal pit (Bogside No.1). Feature B is precisely associated with a small topographic high containing a waste mound. The mound lies in the vicinity of the former Bartonholm coal pit. Feature $C$ shows an association with the former Redburn colliery. Feature $D$ is located within a former artillery and target range. Feature $\mathrm{E}$ is a general area that shows an association with a former mineral railway. Feature $F$ defines an area within the former Ardeer colliery. Feature $G$ is located on the site of the former Ardeer iron works. The broad area labelled $\mathrm{H}$ is centred on the former Misk colliery. The larger area labelled I lies to the east of former collieries, together with former chemical and iron works. It is bounded to the north by a mineral railway that dates back to pre-1860. A number of the very small features in the NW can also be traced to associations with very old (pre1860), small scale open pit workings. Although the values and areas identified in Figure 8 are not excessive compared to some NORM contributions from bedrock geology, the example serves to illustrate the degree to which former industrial activities appear to have left small concentrations of radioactivity in the UK environment. 


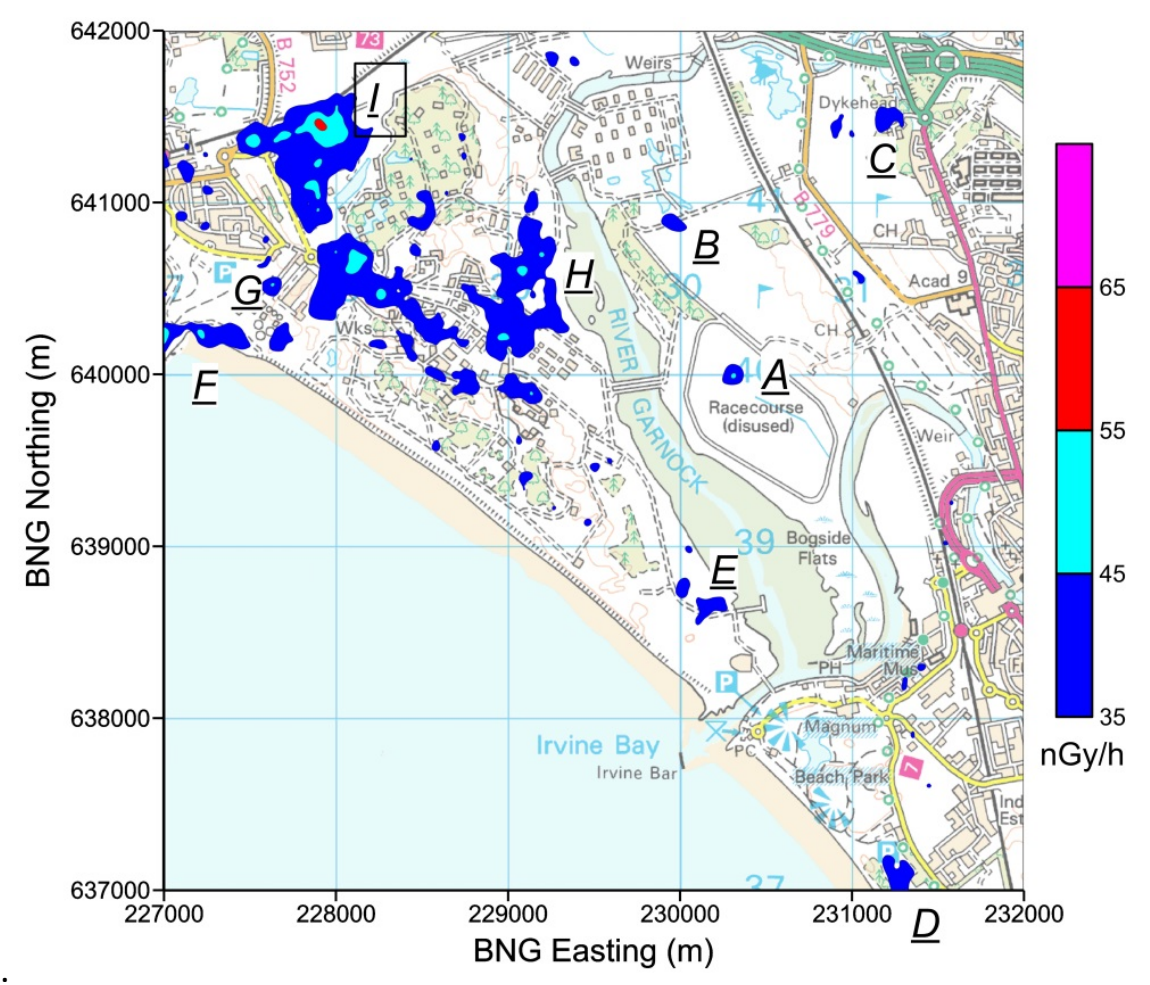

Figure 10. Contours of dose rate values across a $5 \times 5 \mathrm{~km}$ coastal area to the west of the Ayr survey. Data values are obtained from a $10 \mathrm{~m}$ grid and colour-coded values above $35 \mathrm{nGy} \cdot \mathrm{h}^{-1}$ are shown. Letters refer to anomalies discussed in the text. The image is shown on an OS 1:50k background topographic map. 
Since dose rate values are calculated according to equation (1), we can only identify enriched natural radionuclides. The main contributions to the high values are Potassium and Thorium with small enhancements in Uranium occurring at sites ' $\mathrm{E}$ ', ' $\mathrm{F}$ ' and ' $\mathrm{H}$ '. The association between high values and likely TECNORM contributions is usually made on the basis of the scale the contributions i.e. there are no known localised variations in soils, superficial and bedrock variations operating at the scale of the high value zones. In order to illustrate the TECNORM analysis conducted, we refer to Feature $B$ (Fig. 10) and show the dose results across a $500 \times 500 \mathrm{~m}$ area in relation to other information. Figure 11a shows a modern air photograph draped on a 3D perspective view (looking north) of the surface DSM (digital surface model) obtained at a $5 \mathrm{~m}$ cell resolution. Towards the centre of the image a mound can be seen located to the south of a generally wet/marshy area. The elevation of the mound is some $5 \mathrm{~m}$ above the general background elevation. Figure $11 \mathrm{~b}$ shows the dose rate values, on the same DSM, imaged and contoured using the $50 \mathrm{~m}$ line-spaced $\mathrm{N}$-S survey data. The high value dose values can be seen to be collocated with the mound, currently covered with vegetation. Figure 11c shows an equivalent view of the historical map from 1911 and the location of the Bartonholm Coal Pit (No. 1) and the associated mineral railway. It is evident that the mound and dose rate high values encompass the former colliery buildings and associated sidings of the mineral railway. The origin of the anomaly, along with other zones across the site, is therefore considered to be a TECNORM contribution. 

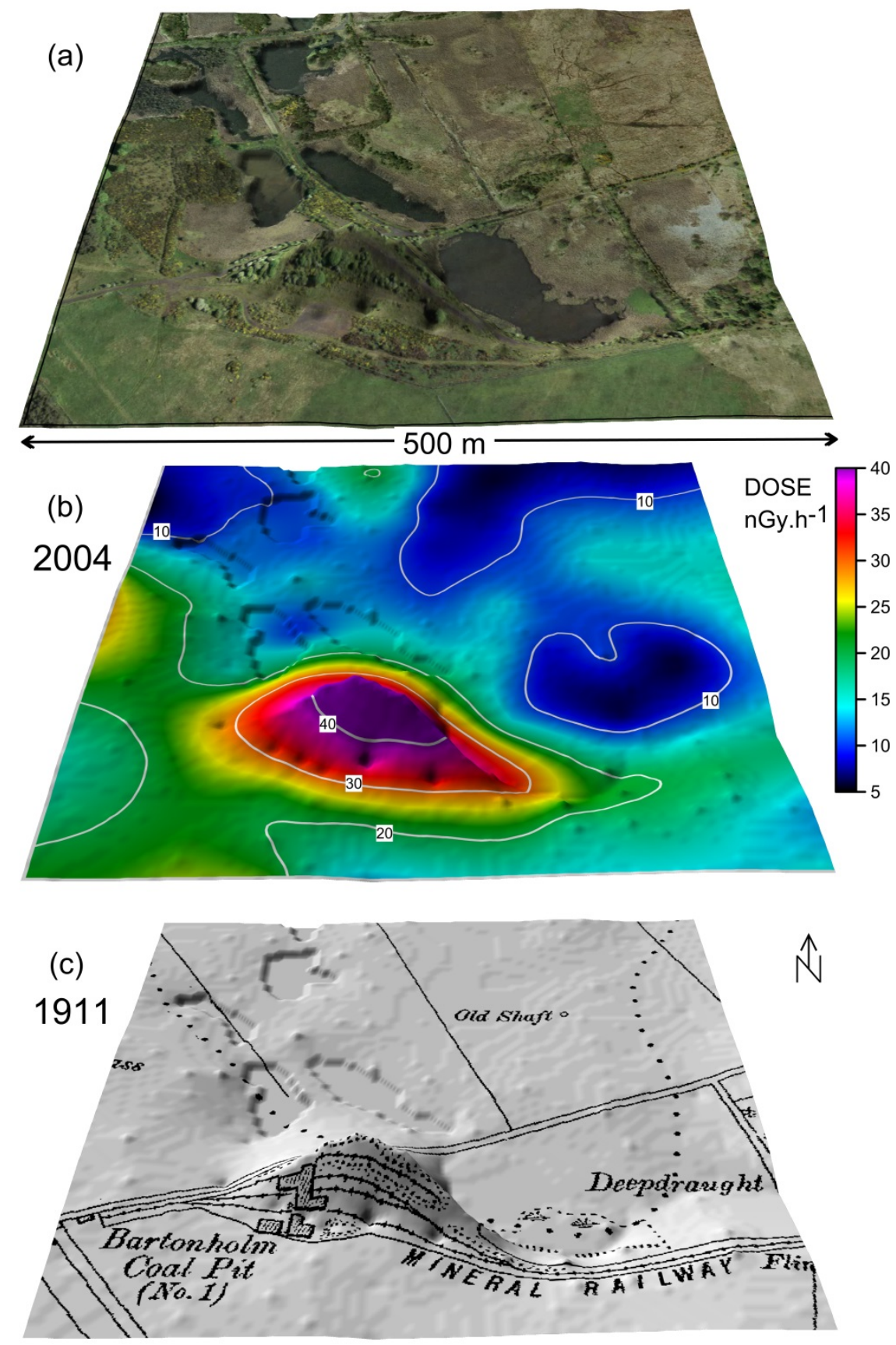

Figure 11. Detailed information across zone B (Fig. 10). The area is $500 \times 500 \mathrm{~m}$ and the 3 views use a 3D perspective view based on a didgital surface elevation model (looking north). (a) Modern air photo. (b) Dose rate estimates shown as a colour image and contours. (c) A historical topographic map from 1911 showing the location of a former coal pit and associated mineral railway.

\subsubsection{Former Uranium Mining}

As can be inferred from Tables 3 and 4, there are only a few occurrences of TENORM dose rates exceeding $100 \mathrm{nGy} \cdot \mathrm{h}^{-1}$. The largest peak value dose response (579 nGy. $\mathrm{h}^{-1}$, Table 3) was observed in the vicinity of the St Austell granite during the TellusSW survey (Figures 1 and 3). The mineralisation of the area is attested to by a wide range of historical mining activities for a variety of minerals particularly iron, tin and Uranium. Figure 12a shows a 3D perspective view of the DOSE observations from a grid $(50 \mathrm{~m})$ of the $200 \mathrm{~m}$ line spacing, $\mathrm{N}-\mathrm{S}$, survey data across a $6 \times 5 \mathrm{~km}$ area. The area lies to 
the SW of the St Austell granite ( $G$ in Fig. 12a). The perimeter of the granite displays a zone of high dose values exceeding $60 \mathrm{nGy} \cdot \mathrm{h}^{-1}$. In the centre of the image a large peak was observed and this is assessed in more detail across the central rectangle shown in Figure 12a. Figure 12b shows the dose rate values observed along individual flight lines. The values are shown by colour and size across five intervals of the observed values. It can be seen that the general background level exceeds $64 \mathrm{nGy} \cdot \mathrm{h}^{-}$ ${ }^{1}$. Within a small zone on one line, however, values exceed $256 \mathrm{nGy} \cdot \mathrm{h}^{-1}$ across 4 locations corresponding to an along-line distance of about $210 \mathrm{~m}$. The background image is a 1909 topographic map which shows a series of shafts and adits together with the former Resugga \& Tolgarick Uranium mine. The mine is currently referred to as South Terras.

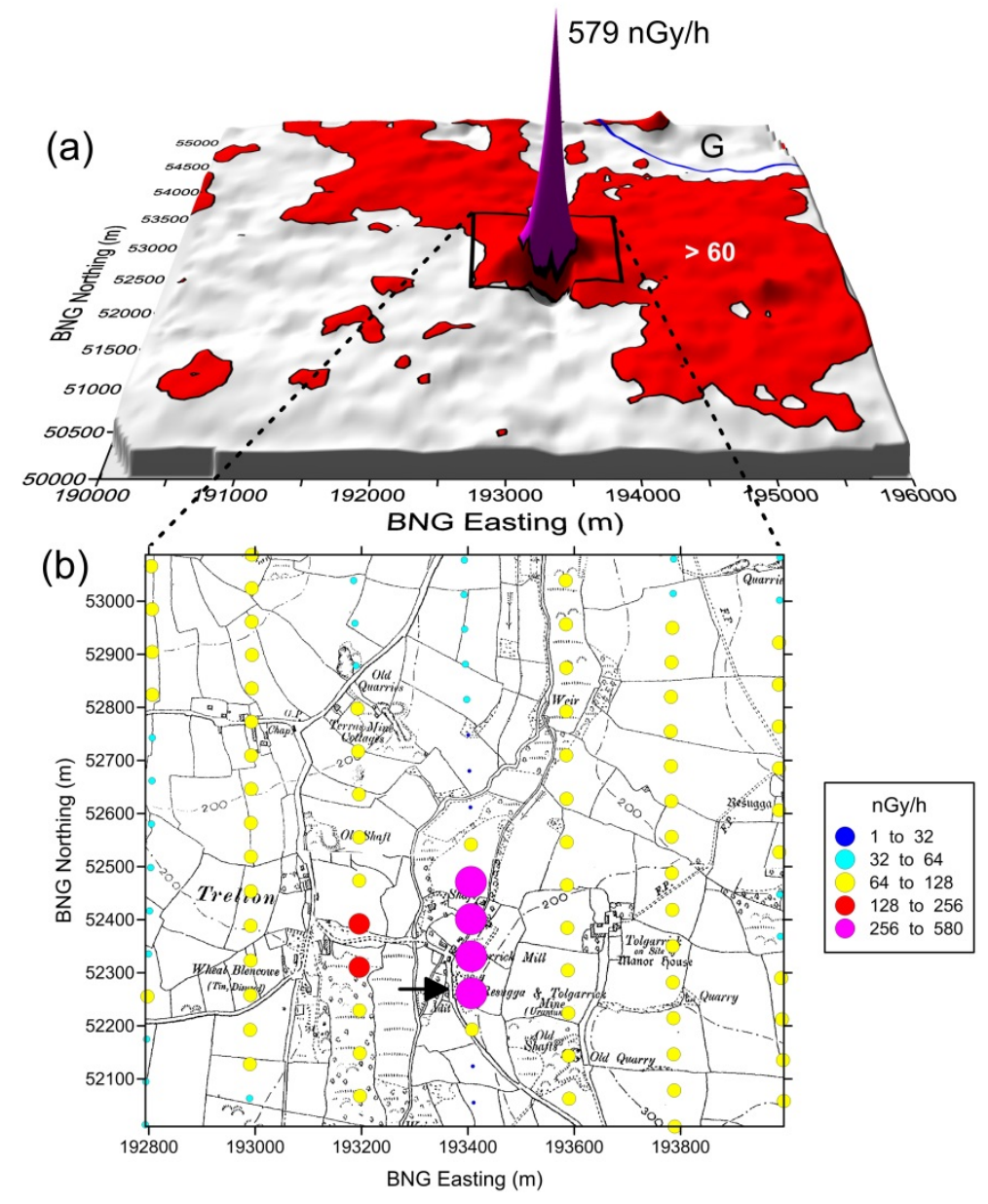

Figure 12. Dose rates observed to the SE of the St Austell granite during the TellusSW survey. (a) Perspective view of dose rate amplitudes with values $>60 \mathrm{nGy} \cdot \mathrm{h}^{-1}$ in red. Rectangle is $6 \times 5 \mathrm{~km}$. G refers to St Austell granite. (b) Detailed, along line, estimates of dose rate shown as colour-size coded values. The background image is a historical topographic map from 1909.

The arrow in Figure $12 \mathrm{~b}$ indicates the existing, gated entrance to the former mine adit, and within the footprint scale of the airborne measurement, high DOSE values are traced primarily to the north with a secondary zone some $200 \mathrm{~m}$ west. Former mine plans indicate Ochre works and dressing floors north of the main adit (arrowed). Radon levels in the mine are known to be hazardous from studies described by Gillmore et al. (2001) who also give a historical account of metalliferous workings at the site. Gillmore et al. (2001) note that even standing $2 \mathrm{~m}$ outside the mine entrance, radon gas levels of $>7,600 \mathrm{~Bq} \cdot \mathrm{m}^{-3}$ may be recorded (values are variable and seasonal). Migration and 
attenuation of Uranium series radionuclides from former and existing spoil zones was studied by Read et al. (1991).

Peak value ground concentrations for the main radionuclides were also high and were recorded as $3.69(\% \mathrm{~K}), 24.0(\mathrm{eTh})$ and $84.2(\mathrm{eU})$. Although radon correction procedures are applied as part of the standard procedures (IAEA, 2003), the upward-looking crystal set within the spectrometer also recorded the highest Uranium values of the survey over this location (104 cps compared with a whole-survey geometric mean of $4 \mathrm{cps}$ ).

\section{Conclusions}

The UK airborne radiometric data considered here cover an onshore area of over $40,000 \mathrm{~km}^{2}$ and sample a substantial range of bedrock lithologies. The high resolution nature of the data ensures that dose rates estimates can be obtained at the local scale (typically 50-70 m resolution) continuously across both urban and rural environments. This has allowed studies of both NORM and TENORM contributions within the data sets. Given that bedrock geology exerts a significant influence on the levels of terrestrial exposure, it is evident that the young sedimentary formations that characterise much of southern England provide the lowest AAD rates while the granitic terrains provide the highest spatially sustained exposure levels. It is found that the young ( $56 \mathrm{Ma}$ ) Mourne granite complex of Northern Ireland is a factor of 2 more radiogenic than the older (>290 Ma) Variscan granites of SW England. A further significant unexpected finding is the extent of a band of spatially-sustained high dose rate values $\left(>50 \mathrm{nGy} \cdot \mathrm{y}^{-1}\right.$ ) associated with the Mercia Mudstone Group (Triassic argillaceous mudstones) of eastern England.

The attenuating properties of the soil cover have been noted and analysed. The attenuation, largely controlled by water content and soil density, provides a reduction in the air absorbed rates that are highly relevant to the UK. Here, and at other temperate latitudes, baseline moisture content levels are likely to be seasonally maintained. Two detailed studies suggest that the influence of the presence or absence of soil cover (and associated presence or absence of attenuation) appears to account for a range of localised variations in the exposure levels encountered. In order to demonstrate the broad levels of dose rate attenuation due to the soil cover, data from an extensive ground geochemical and airborne sampling across Northern Ireland were used to assess dose rates from over 6,800 approximately co-located observations. The comparison uses soil sample estimates obtained from the depth interval from $5-20 \mathrm{~cm}$ and demonstrates a clear and unequivocal offset between the two sets of dose estimates and individual radioelement contributions. The observed soil sample estimates are not corrected for attenuation and display a bias increase of between 10 and $15 \mathrm{nGy} . \mathrm{h}^{-1}$. The behaviour is also evident in other UK ground geochemical and airborne datasets, not reported here. It is noted that in order to directly compare in-air estimates of dose rates, obtained from either ground or airborne spectrometry, with soil/laboratory estimates, theory indicates that knowledge of the moisture content, density and porosity is required across the appropriate depth range of the soil sampled profile.

Due to the wide-spread environmental legacy of historical industrial activity across the UK, a range of technologically enhanced dose rate contributions have been studied using airborne and ground based data. These relate to colliery spoil, power station fly-ash, iron-ore mines and processing plants. Here a very high-resolution case study illustrates the degree to which former industrial 
activities appear to have left small concentrations of radioactivity (e.g. $<50 \mathrm{nGy} \cdot \mathrm{h}^{-1}$ ) in the UK environment. Areas of mineral mining, such as those found in SW England and Derbyshire, have produced sufficient concentrations of near-surface radiogenic materials to account for a small number of dose rates values exceeding the highest background geological levels (i.e. those found across granites). Due to the spatial averaging, inherent to the airborne measurement, ground observations of exposure will typically locally diverge from the estimates described here.

\section{Acknowledgements}

My thanks go to Antonio Ferreira for an extensive internal review. The Northern Ireland data used in the study come from the Tellus Project which was funded by DETI and by the Building Sustainable Prosperity scheme of the Rural Development Programme (Department of Agriculture and Rural Development of Northern Ireland). Topographic map data based upon Ordnance Survey data with the permission of the Controller of Her Majesty's Stationery Office, (C) Crown copyright. Countryside Survey data owned by NERC e Centre for Ecology \& Hydrology. This paper is published with the permission of the Executive Director, British Geological Survey (NERC). 


\section{References}

Appleton, J.D., Miles, J.C.H., Green, B.M.R., Larmour, R., 2008. Pilot study of the application of Tellus airborne radiometric and soil geochemical data for radon mapping. Journal of Environmental Radioactivity 99, 1687-1697.

Beamish, D. Cuss, R.J.,Lahti, M.,Scheib, C.,Tartaras, E., 2006. The Tellus airborne geophysical survey of Northern Ireland : final processing report. British Geological Survey, Internal Report IR/06/136.

Beamish, D. and White, J.C., 2011. A radiometric airborne geophysical survey of the Isle of Wight, Proceedings of the Geologists' Association 122, 787-799.

Beamish, D., 2013. Gamma ray attenuation in the soils of Northern Ireland, with special reference to peat. Journal of Environmental Radioactivity 115, 13-27.

Beamish, D., 2014. Peat mapping associations of airborne radiometric survey data. Remote Sensing 6, 521-539.

Beamish, D. and White, J., 2014 TellusSW : airborne geophysical data and processing report. British Geological Survey Open Report OR/14/014.

Beamish, D., Howard, A., Ward, E.K., White, J., Young, M. E., 2014. Tellus South West airborne geophysical data. NERC-Environmental Information Data Centre. Doi: 10.5285/73848363-57c1-480aa64e-c732e15c4b37.

Billings, S., Hovgaard, J., 1999. Modelling detector response in airborne gamma-ray spectrometry. Geophysics 64, 1378-1392.

BGS (2008). Digital Geological Map of Great Britain 1:625 000 scale (DiGMapGB-625), bedrock data. Version 5.17. Release date 11-02-2008. Keyworth, Nottingham, British Geological Survey.

Carroll, T.R., 1981. Airborne soil moisture measurement using natural terrestrial gamma radiation. Soil Science 132, 358-366.

Caulfield, J.J., Ledgerwood, F. K. 1989. Terrestrial gamma-ray dose rates out of doors in Northern Ireland. Department of the Environment for Northern Ireland Environmental Monitoring Report No. 2.

Cook, S. E., Corner, R.J., Groves, P.R. and Grealish, G.J., 1996. Use of airborne gamma-radiometric data for soil mapping. Australian Journal of Soil Research 34, 183-194.

Duval, J.S., Cook, B., Adams, A.S., 1971. Circle of Investigation of an airborne gamma-ray spectrometer. Journal of Geophysical research 76, 8466-8470.

Emery, C, Hodgkinson, E, Jones, D, Davis, J, Strutt, M., 2005a. Investigation of airborne and groundbased radiometric data with soil gas radon to assess variability of indoor radon potential for the Carboniferous limestone of Derbyshire. British Geological Survey Internal Report IR/05/061. 
Emery, C., Davis, J.R., Hodgkinson, E., Jones, D.G., 2005b. Airborne and ground-based radiometric investigation of colliery spoil near Shirebrook, the English Midlands. British Geological Survey Internal Report IR/05/059.

Emmett, B.A., Reynolds, B., Chamberlain, P.M., Rowe, E., Spurgeon, D., Brittain, S.A., Frogbrook, Z., Hughes, S., Lawlor, A.J., Poskitt, J., Potter, E., Robinson, D.A., Scott, A., Wood, C., Woods, C., 2010. Countryside Survey: Soils Report from 2007. Technical Report No. 9/07 NERC/Centre for Ecology \& Hydrology 192pp. (CEH Project Number: C03259).

Gillmore, G. K., Phillips, P. S., Denman, A. R., Sperrin, M., Pearce, G. (2001) Radon levels in abandoned metalliferous mines, Devon, Southwest England. Ecotoxicology and Environmental Safety 49, 281-292.

Grasty, R.L.,Minty, B.R.S., 1995. A guide to the technical specifications for airborne gamma-ray surveys. Australian Geological Survey Organisation, Record 1995/60.

Grasty, R.L., 1997. Radon emanation and soil moisture effects on airborne gamma ray measurements. Geophysics 62, 1379-1385.

Green, B.M.R., Lomas, P.R., Bradely, E J., Wrixon, A D., 1989. Gamma-radiation levels outdoors in Great Britain. NRPB-R191 (London; HMSO).

Hodgkinson, E., Scheib, C., Jones, D.G., Davis, J. 2006. Studies of possible controls on the variability of radon potential of two East Midlands ironstones. British Geological Survey Internal Report IR/06/128.

Howard, A.S., Warrington, G., Carney, J. N., Ambrose, K., Young, S.R., Pharaoh., T.C., Cheney, C.R., 2009. Geology of the Nottingham district : memoir for 1:50 000 geological sheet 126 (England and Wales). British Geological Survey, Nottingham, UK.

Hughes, J.S., Watson, S.J., Jones, A.L., Oatway, W.B., 2005. Review of the radiation exposure of the UK population. Journal of Radiological Protection 25, 493-496.

IAEA, 1991. Airborne gamma ray spectrometer surveying. International Atomic Energy Agency, Vienna, Technical Report Series, No. 323.

IAEA, 2003. Guidelines for radioelement mapping using gamma ray spectrometry. International Atomic Energy Agency, Vienna, Technical Report Series, No. 136.

IAEA, 2010. Radioelement Mapping. International Atomic Energy Agency, Vienna, Nuclear Energy Series, No. NF-T-1.3.

ICRU (International Commission on Radiation Units and Measurements), 1994. Gamma-Ray Spectrometry in the Environment. ICRU Report 53.

Johnson C.C. and Breward, N., 2004 G-Base: Geochemical Baseline Survey of the Environment. British Geological Survey Internal Report CR/04/016.

Johnson, C.C., Breward, N., Ander, E. L., Ault, L., 2005 G-Base: baseline geochemical mapping of Great Britain and Northern Ireland. Geochemistry: Exploration-Environment-Analysis, 5, 4, 347-357. 
Kestell, D.J., 2000. An investigation of the distribution and radiological Impact of naturally radionuclides in industrial spoil heaps. MSc Thesis, University of Surrey. British Geological survey.

Kock, P., Samuelsson, C., 2011. Comparison of airborne and terrestrial gamma spectrometry measurements - evaluation of three areas in southern Sweden. Journal of Environmental Radioactivity 102, 605-613.

Lahti, M., Jones, D.G., 2003. Environmental applications of airborne radiometric surveys. First Break 21, 35-41.

Løvborg, L., 1984. The calibration of portable and airborne gamma-ray spectrometers - theory, problems and facilities. Ris $\varnothing$ Report M-2456, pp. 207.

Macdonald, J., Smith, P.H., Assinder, D.J., 1996. The development and use of an in situ gamma-ray spectrometry system in North Wales. Journal of Radiological Protection 16, $115^{-1} 27$.

Minty, B.R.S., 1967. Fundamentals of airborne gamma-ray spectrometry. AGSO Journal of Australian Geology and Geophysics 17, 39-50.

Minty, B.R.S., Luyendyk, A.P.J., Brodie, R.C., 1967. Calibration and data processing for airborne gamma-ray spectrometry. AGSO Journal of Australian Geology and Geophysics 17, 51-62.

Pitkin, J. A., Duval, J. S., 1980. Design parameters for aerial gamma ray surveys. Geophysics 45, 1427-1439.

Rawlins, B.G., Scheib, C., Beamish, D., Webster, R. and Young, M.E., 2011. Landscape-scale controls on the spatial distribution of caesium-137: A study based from an airborne geophysical survey across Northern Ireland. Earth Surface Processes and Landforms 35, 158-169.

Read, D., Hooker, P.J., Ivanovich, M., Milodowski, A.E., 1991. A natural analogue study of an abandoned uranium mine in Cornwall, England. Radiochimica Acta 52, 349-356.

Sanderson, D.C.W., Cresswell, A.J., Lang, J.J.. 2002. An international comparison of airborne and ground based gamma ray spectrometry (ECCOMAGS). Scottish Universities Environmental Research Council. ISBN 0852617836.

Scheib C., Beamish, D., 2010. High spatial resolution observations of ${ }^{137} \mathrm{Cs}$ in northern Britain and Ireland from airborne geophysical survey. Journal of Environmental Radioactivity 101, 670-680.

Scheib, C., Appleton, J.D., Miles, J.C.H., Hodgkinson, E., 2013. Geological controls on radon potential in England. Proceedings of the Geologists' Association 124, 910-928.

Smith, A., 2011. Digital Geological Map of Great Britain, information notes, 2011. British Geological Survey Open Report, OR/10/050.

Smyth, D. 2007. Methods used in the Tellus Geochemical Mapping of Northern Ireland British Geological Survey Open Report, OR/07/022. 90pp. 
Taylor, M.J., Smettem, K., Pracillio, G., Verboom, W., 2002. Relationships between soil properties and high-resolution radiometrics, central eastern Wheatbelt, Western Australia. Exploration Geophysics 33, 95-102.

Tauchid, M., Grasty, R.L., 2002. Natural Background Radioactivity of the Earth's Surface - Essential Information for Environmental Impact Studies, C\&S Papers Series 10/P, IAEA, Vienna, 230-242.

Tyler, A.N., 1994. Environmental influences on gamma ray spectrometry. PhD thesis, University of Glasgow.

Tyler, A.N., Copplestone, D. 2007. Preliminary results from the first national in situ gamma spectrometry survey of the UK. Journal of Environmental Radioactivity 96, 94-102.

Tyler, A.N., D.C.W. Sanderson, E.M. Scott, \& J.D. Allyson, 1996. Investigations of Spatial Variability and Fields of View in Environmental Gamma Ray Spectrometry. Journal of Environmental Radioactivity 33, 213-235.

UNSCEAR (United Nations Scientific Committee on the Effects of Atomic Radiation), 1977. Report to the General Assembly, with Annexes. Sources and Effects of Ionizing Radiation, United Nation, New York, 725.

UNSCEAR (United Nations Scientific Committee on the Effects of Atomic Radiation), 2000. United Nations Scientific Committee on the Effects of Atomic Radiation Report to the General Assembly, with Annexes. Sources and Effects of Ionizing Radiation, Vol. I: Sources, United Nation, New York, 654.

Watson, S. J., Jones, A. L., Oatway, W. B., Hughes, J. S., 2005. HPA-RPD-001 - Ionising Radiation Exposure of the UK Population: 2005 Review. ISBN 0-85951-558-3.

White, J.C, Beamish, D. and Cuss, R.J., 2009. The HiRES airborne geophysical survey of the Isle of Wight: Processing Report. British Geological Survey, Open Report OR/09/060. 